Review

\title{
Clinical Pharmacology of Furosemide in Neonates: A Review
}

\section{Gian Maria Pacifici}

Section of Pharmacology, Department of Translational Research and New Technologies in Medicine and Surgery, University of Pisa, Pisa 56100, Italy; E-Mail: pacifici@biomed.unipi.it; Tel: +39-050-2218-721; Fax: +39-050-2218-717.

Received: 16 April 2013; in revised form: 28 August 2013 / Accepted: 30 August 2013 / Published: 5 September 2013

\begin{abstract}
Furosemide is the diuretic most used in newborn infants. It blocks the $\mathrm{Na}^{+}-\mathrm{K}^{+}-2 \mathrm{Cl}^{-}$symporter in the thick ascending limb of the loop of Henle increasing urinary excretion of $\mathrm{Na}^{+}$and $\mathrm{Cl}^{-}$. This article aimed to review the published data on the clinical pharmacology of furosemide in neonates to provide a critical, comprehensive, authoritative and, updated survey on the metabolism, pharmacokinetics, pharmacodynamics and side-effects of furosemide in neonates. The bibliographic search was performed using PubMed and EMBASE databases as search engines; January 2013 was the cutoff point. Furosemide half-life $\left(\mathrm{t}_{1 / 2}\right)$ is 6 to 20 -fold longer, clearance $(\mathrm{Cl})$ is 1.2 to 14 -fold smaller and volume of distribution ( $\mathrm{Vd}$ ) is 1.3 to 6 -fold larger than the adult values. $\mathrm{t}_{1 / 2}$ shortens and $\mathrm{Cl}$ increases as the neonatal maturation proceeds. Continuous intravenous infusion of furosemide yields more controlled diuresis than the intermittent intravenous infusion. Furosemide may be administered by inhalation to infants with chronic lung disease to improve pulmonary mechanics. Furosemide stimulates prostaglandin E2 synthesis, a potent dilator of the patent ductus arteriosus, and the administration of furosemide to any preterm infants should be carefully weighed against the risk of precipitation of a symptomatic patent ductus arteriosus. Infants with low birthweight treated with chronic furosemide are at risk for the development of intra-renal calcifications.
\end{abstract}

Keywords: furosemide; neonate; metabolism; pharmacokinetics; pharmacodynamics; continuous infusion; extracorporeal membrane oxygenation; side-effects 


\section{Introduction}

Diuretics increase the rate of urine flow and $\mathrm{Na}^{+}$excretion and are used to adjust the volume and/or the composition of body fluids. The basic urine-forming unit of the kidney is the nephron, which consists of a filtering apparatus, the glomerulus, connected to a long tubular portion that reabsorbs and conditions the glomerular ultrafiltration. Furosemide increases the delivery of solutes out of the loop of Henle, is a sulphonamide derivative, and is the most commonly used diuretic in the newborn period [1,2]. Given in excessive amounts, furosemide can lead to dehydration and electrolytic depletion [3].

Around the year 1960 "loop" diuretics (furosemide, ethacrynic acid and bumetanide) were developed. These block the $\mathrm{Na}^{+}-\mathrm{K}^{+}-2 \mathrm{Cl}^{-}$cotransport system in the ascending limb [4] and inhibit $\mathrm{Na}^{+}$, $\mathrm{Cl}^{-}$and $\mathrm{K}^{+}$entering the tubular cell. Loop diuretics are highly efficacious, and for this reason, are called "high-ceiling-diuretics".

The flux of $\mathrm{Na}^{+}, \mathrm{K}^{+}$and $\mathrm{Cl}^{-}$from the lumen into the epithelial cells in the thick ascending limb is mediated by a $\mathrm{Na}^{+}-\mathrm{K}^{+}-2 \mathrm{Cl}^{-}$symporter. This symporter captures free energy in the $\mathrm{Na}^{+}$electrochemical gradient established by the basolateral $\mathrm{Na}^{+}$pump and provides for "uphill" transport of $\mathrm{K}^{+}$and $\mathrm{Cl}^{-}$into the cell. Abolition of the transepithelial potential difference also results in a marked increase in $\mathrm{Ca}^{2+}$ and $\mathrm{Mg}^{2+}$ excretion, with consequent increase of urine $\mathrm{pH}$.

Furosemide has weak carbonic anhydrase-inhibiting activity. Drugs with carbonic anhydrase-inhibiting activity increase urinary excretion of $\mathrm{HCO}_{3}{ }^{-}$and phosphate. By blocking active $\mathrm{NaCl}$ reabsorption in the thick ascending limb, furosemide interferes with a critical step in the mechanism that produces a hypertonic medullary interstitium. Therefore, furosemide blocks the kidney's ability to concentrate urine during hydropenia [3].

Furosemide binds extensively to plasma proteins and bilirubin displacement is negligible when using normal doses of furosemide. Delivery of this drug to the tubules by filtration is limited and it enters the tubules by tubular secretion. In adults, average bioavailability of furosemide is $71 \pm 35 \%$ and it ranges from $43 \%$ to $73 \%$ [5]. In neonates, mean bioavailability is $84.3 \%$ (range $56 \%$ to $106 \%$ ) [6]. In infants, time to peak effect when given intravenously is 1 to $3 \mathrm{~h}$ [7]. There is a remarkable interindividual variability in the kinetic parameters of furosemide in neonates. The half-life $\left(\mathrm{t}_{1 / 2}\right)$ is 6 to 20 -fold longer, clearance $(\mathrm{Cl})$ is 1.2 to 14 -fold smaller and volume of distribution $(\mathrm{Vd})$ is 1.3 to 6 -fold larger than the adult values.

In neonates, duration of the effect is approximately $6 \mathrm{~h}$, although half-life $\left(\mathrm{t}_{1 / 2}\right)$ may be as long as $67 \mathrm{~h}$ in the most immature newborn infants [7]. Furosemide may be administered as intravenous continuous infusion and yields more controlled diuresis as compared with intermittent intravenous infusion. Extra corporeal membrane oxygenation (ECMO) is a potentially life-saving therapy for neonates suffering from severe respiratory failure. The most common diagnosis for which ECMO is performed are diaphragmatic hernia, meconium aspiration syndrome, and pneumonia [8]. The variable renal function, and the altered furosemide pharmacokinetics, that range from 0.02 to $0.17 \mathrm{mg} / \mathrm{kg} / \mathrm{h}$ [9], make the dosing schedule of furosemide for ECMO largely empirical. Furosemide may be administered by inhalation to preterm infants with chronic lung disease [10] to improve pulmonary mechanics [11].

Furosemide stimulates the renal synthesis of prostaglandin E2 [12], a potent dilator of the patent ductus arteriosus, and the administration of furosemide to any patient with respiratory distress syndrome should be carefully weighed against the risk of precipitation of a symptomatic patent ductus arteriosus $[11,13]$. 
Furosemide can cause ototoxicity that manifests as tinnitus, hearing impairment, deafness, vertigo, and a sense of fullness in the ears [3]. Hearing impairment and deafness are usually, but not always, reversible. Ototoxicity occurs most frequently with rapid intravenous administration and least frequently with oral administration [3]. Heidland and Wigand [14] suggested that furosemide should be given at a rate less than $4 \mathrm{mg} / \mathrm{min}$ to adult patients to avoid hearing loss. In infants, furosemide blood levels should not exceed $50 \mu \mathrm{g} / \mathrm{mL}$ [15]. The chronic treatment of furosemide to low birthweight infants may develop intra-renal calcification [16]. The vulnerability of extreme immaturity and the underdevelopment of renal function may be the most important variables. Hypercalciuria is common in very low birthweight infants, yet not all develop nephrocalcinosis.

The work on the clinical pharmacology of furosemide in neonates was published in different journals during the period 1970 to 2013 and the relative information is scattered. The present article aims to gather together and to review the studies on the metabolism, pharmacokinetics, pharmacodynamics and side-effects of furosemide in neonates to provide a critical, comprehensive, authoritative, and updated analysis of literature.

\section{Bibliographic Search}

The bibliographic search was performed electronically using PubMed and EMBASE databases as search engines; January 2013 was the cutoff point. The following key words were used: "diuretics neonate", "furosemide neonate", "pharmacokinetics furosemide neonate", "metabolism furosemide neonate", "continuous infusion furosemide neonate", "extracorporeal-membrane-oxygenation furosemide neonate", "inhaled furosemide neonate", "furosemide patent ductus arteriosus" "ototoxicity furosemide neonate" "furosemide nephrocalcinosis neonate" "furosemide hypercalcemia neonate" "furosemide hydrocephalus neonate" and "side-effects furosemide neonate". The bibliography of each article was read carefully, and the selected articles were examined. The references were copied by PubMed, were pasted to the manuscript and were edited according the style of Pharmaceuticals. In addition, the books NEOFAX: a Manual Used in the Neonatal Care by Young and Mangum [7] and Neonatal Formulary [10] were consulted. The findings of the bibliographic search gave rise to 120 original articles, 29 review articles and five book chapters. The publication years of this matter ranged from 1961 to 2012.

\section{Biological Characteristics of Neonates}

\subsection{Total Body Water and Extracellular Water in Newborn Infants}

Total body water was measured in 21 newborn infants with mean body weight of 3,320 g and mean total body water was found to be $78.4 \%$. In subjects $10-15$ years old, the total body water is $57.3 \%$ [17]. The extracellular water is $44.5 \%$ in neonates and $18.7 \%$ in subjects $10-15$ years old [17]. In adults, $\mathrm{Vd}$ of furosemide is $0.13 \mathrm{l} / \mathrm{kg}$ [5] suggesting that furosemide is mainly distributed into the extracellular water. The larger $\mathrm{Vd}$ of furosemide in neonates than in adults may be due to the larger extracellular water in neonates into which furosemide is distributed. 


\subsection{Extracellular Volume in Neonates}

The extracellular volume was measured in 14 preterm infants, with a gestational age and a birthweight of $30.7 \pm 2.4$ weeks and 1,473 $\pm 342 \mathrm{~g}$, respectively, on days 1 and 7 of postnatal age. The extracellular volume decreased from $725 \pm 159 \mathrm{~mL}$ on day 1 to $516 \pm 119 \mathrm{~mL}$ on day $7(p<0.001)$ of postnatal age [18]. Thus, the extracellular volume decreases with the neonatal maturation. The drugs that are confined into the extracellular volume reach higher concentrations on day 7 than on day 1 of postnatal age.

\subsection{Glomerular Filtration Rate in Neonates}

Nephrogenesis is completed by the end of the 34th week of gestation [19]. The kidney of a full-term neonate possesses approximately 850,000 to $1,200,000$ nephrons per kidney [19], but some events during pregnancy such as growth retardation, nephrotoxic drugs administered to the mother or renal/urologic fetal malformations may negatively influence the number of nephrons [20-22]. Glomerular filtration rate (GFR) depends on the number of nephrons, the mean arterial blood pressure, renal plasma flow, and the intra-renal resistance [23]. GFR in neonates is $2-4 \mathrm{~mL} / \mathrm{min}$ and can only be maintained due to a delicate balance between vasodilatory effects at the afferent and vasoconstrictor effects at the efferent glomerular arterioles [19,21,24,25]. In adults, GFR is $120 \mathrm{~mL} / \mathrm{min}$ [26]. There is an impressive postnatal increase in GFR postnatally, as it increases with a mean of $0.19 \mathrm{~mL} / \mathrm{min}$ during the 7-day period between day 3 and day 10 after birth [21].

\subsection{Tubular Function}

The ultra-filtrate is modified through re-absorption and secretion processes in the different parts of the tubular system. Secretory and absorptive tubular processes are relatively well developed at birth, postnatal maturational changes occur [27]. Preterm infants have immature glomerular and tubular functions [27]. The fractional excretion of $\mathrm{Na}^{+}$is an efficient index of tubular function [28]. The fractional excretion of $\mathrm{Na}^{+}$directly after birth can be as high as 5\% [29]. In premature infants, the fractional excretion of $\mathrm{Na}^{+}$value correlated negatively with the postnatal age and the velocity of decrease was directly correlated with age [29]. In fullterm neonates, the fractional excretion of $\mathrm{Na}^{+}$ falls within hours [29].

\subsection{The Loop of Henle}

Functionally, the loop of Henle plays an important part in the ability to generate a concentrated urine. The descending limb of Henle's loop, however, is thought to be permeable to $\mathrm{Na}^{+}, \mathrm{K}^{+}, \mathrm{Cl}^{-}$, water and urea. Permeability to $\mathrm{Ca}^{+}$appears to be low [30]. Under normal circumstances, water reabsorption occurs, and the osmolality of the tubular fluid and the concentration of urea, $\mathrm{Na}^{+}$and $\mathrm{Cl}^{-}$ increase along the descending limb [30]. Significant passive reabsorption of $\mathrm{Na}^{+}$and $\mathrm{Cl}^{-}$occurs along the thin ascending limb. Reabsorption of up to $25 \%$ of filtrated $\mathrm{Na}^{+}$and $\mathrm{Cl}^{-}$occurs in the medullary and cortical portions of the thick ascending limb [30]. Because the thick ascending limb is relatively impermeable to water, the osmolality of the tubular fluid falls progressively as solute reabsorption occurs. Approximately 20 to $25 \%$ of the filtered $\mathrm{Ca}^{+}$is reabsorbed in this nephron segment [30]. 


\subsection{Renal Clearance in Neonates}

Clearance of drugs in neonates is slow compared with that of adults and older children, because of the relative inefficiency of renal function and lower capacity to eliminate drugs [24]. GFR matures during infancy to approach the adult rate $(6 \mathrm{~L} / \mathrm{h} / 70 \mathrm{~kg})$ from 6 months of postnatal life [23,31-34]. Growth restriction has an important negative effect on the normalized weight of the kidney, on the number of nephrons, on the GFR, and on tubular function in human perinatal life [35-39]. Infants small for gestational age have additional impact on $\mathrm{Cl}$ of drugs, such as the aminoglycosides or glycopeptides that are mainly cleared through the kidney. Maturation of both amikacin and vancomycin clearance is closely aligned with GFR maturation in neonates [32-34]. Small for gestational age preterm neonates in the first month of life have a mean reduction of $16.2 \%$ in renal drug clearance [23]. Intrauterine growth retardation has an unfavourable impact on renal tubular function [23].

\subsection{Urine Output in Preterm Infants}

Urine output was measured by Kushnir and Pinheiro [40] in 185 preterm infants with a gestational age and a body weight of 27.8 weeks and $1083 \mathrm{~g}$, respectively. Urine output (mean \pm SD) was $4.2 \pm 1.6 \mathrm{~mL} / \mathrm{kg} / \mathrm{h}$.

\subsection{Renal Glomerular and Tubular Functional and Structural Integrity in Neonates}

Renal functional capacity is lower in the newborns than in adults [41]. Renal cells are not fully differentiated at birth and many of the differences in renal function seen between infants and adults should be attributed to immaturity [42]. Preterm infants have immature renal function with respect to both glomerular and tubular function [29]. Plasma creatinine concentration on day 1 of postnatal life is a poor guide to an infant's renal function because it mainly reflects the maternal creatinine origin [43]. A more precise assessment of the renal functional capacity is made by measuring the GFR. In very low birthweight infants, GFR is only $67 \%$ of that of fullterm infants [44]. The development of tubular function lags behind that of the glomerulus [45].

Urinary excretion of high molecular weight proteins, especially albumin and immunoglobulin $G$ $(\mathrm{IgG})$, is the best marker of glomerular dysfunction [46], whereas urinary excretion of low molecular weight proteins, such as $\alpha_{1}$-microglobulin $\left(\alpha_{1} \mathrm{M}\right)$, retinol binding protein (RPB) and $\beta_{2}$-microglobulin $\left(\beta_{2} \mathrm{M}\right)$ are recommended as potential markers for detecting tubular dysfunction [29].

The metabolic organization of the nephron has been assessed and about 12 segments have been distinguished according to their enzymatic activities. Brush-border, liposomal, and cytosolic enzymes are excreted in the urine of healthy subjects and enzymuria is expected to rise as a consequence of cell breakdown, necrosis and increased cellular turnover [47]. Therefore, the type of enzymuria reflects the site of damage to proximal tubules. Of these urinary enzymes, the brush-border membrane enzyme leucine-aminopeptidase (LAP [48]) and the lysosomal N-acetyl- $\beta$-D-glucosaminidase (NAG [49]) were recommended as markers for investigating the structural integrity of renal proximal tubules.

Table 1 shows a significant difference between days 1 and 3 in serum creatinine and urinary IgG levels among diseased preterm newborns suggesting that a glomerular dysfunction may develop in 3 days of postnatal life. Healthy preterm newborns revealed a significant difference between days 1 
and 3 with respect to urinary $\alpha_{1} \mathrm{M}$ level and NAG activities indicating that in 3 days of postnatal life proximal tubular reabsorption and structure improve.

Table 1. Glomerular function, proximal tubular reabsorption function, proximal tubular structure integrity and distal reabsorption capacity in healthy fullterm infants, healthy preterm infants and diseased preterm infants on days 1 and 3 of postnatal life. Figures are the mean $\pm \mathrm{SD}$ and analyzed using paired t test for parametric data. From Awad et al. [29].

\begin{tabular}{|c|c|c|c|c|c|c|}
\hline \multirow{2}{*}{ Parameters } & \multicolumn{2}{|c|}{ Healthy fullterm $(n=10)$} & \multicolumn{2}{|c|}{ Healthy preterm $(n=10)$} & \multicolumn{2}{|c|}{ Diseased preterm $(n=30)$} \\
\hline & Day 1 & Day 3 & Day 1 & Day 3 & Day 1 & Day 3 \\
\hline \multicolumn{7}{|c|}{ Glomerular function } \\
\hline Cr Conc. (mg/dL) & $0.79 \pm 0.14$ & $0.77 \pm 0.19$ & $0.86 \pm 0.21$ & $0.84 \pm 0.16$ & $0.81 \pm 0.15$ & $0.95 \pm 0.18^{\mathrm{a}}$ \\
\hline Microalbuminuria ( $\mu \mathrm{g} / \mathrm{mg} \mathrm{Cr})$ & $197 \pm 245$ & $157 \pm 120$ & $292 \pm 263$ & $154 \pm 147$ & $332 \pm 263$ & $334 \pm 363$ \\
\hline Urinary $\operatorname{IgG}(\mathrm{g} / \mathrm{mg} \mathrm{Cr})$ & $0.02 \pm 0.05$ & $0.003 \pm 0.01$ & & & $0.22 \pm 0.26^{b}$ & $0.05 \pm 0.15^{\mathrm{a}}$ \\
\hline \multicolumn{7}{|c|}{ Proximal tubular reabsorption function } \\
\hline Urinary $\alpha_{1} \mathrm{M}(\mathrm{g} / \mathrm{mg} \mathrm{Cr})$ & $99.5 \pm 84.9$ & $64.8 \pm 55.3$ & $278 \pm 235^{\mathrm{c}}$ & $72.3 \pm 56.7^{\mathrm{a}}$ & $195 \pm 117$ & $215 \pm 171^{\mathrm{d}}$ \\
\hline Urinary $\beta_{2} \mathrm{M}(\mu \mathrm{g} / \mathrm{mg} \mathrm{Cr})$ & $1.56 \pm 2.48$ & $4.89 \pm 7.11$ & $3.29 \pm 4.69$ & $6.12 \pm 10.0$ & $6.29 \pm 4.61$ & $8.10 \pm 9.88$ \\
\hline Urinary RBP $(\mu \mathrm{g} / \mathrm{mg} \mathrm{Cr})$ & $1.11 \pm 1.69$ & $1.22 \pm 1.74$ & $1.99 \pm 2.50$ & $1.20 \pm 1.02$ & $2.71 \pm 2.10$ & $3.04 \pm 2.35^{\mathrm{d}}$ \\
\hline \multicolumn{7}{|c|}{ Proximal tubular structure integrity } \\
\hline Urinary LAP (U/g Cr) & $0.28 \pm 0.72$ & $0.08 \pm 0.06$ & $0.47 \pm 0.90$ & $0.20 \pm 0.43$ & $0.54 \pm 0.75$ & $0.21 \pm 0.26$ \\
\hline Urinary NAG (nmol/min/mg Cr) & $133 \pm 192$ & $97.7 \pm 114$ & $407 \pm 395$ & $108 \pm 210^{\mathrm{a}}$ & $521 \pm 582$ & $427 \pm 474^{\mathrm{d}}$ \\
\hline \multicolumn{7}{|c|}{ Distal reabsorption capacity FeNa\% } \\
\hline $\mathrm{FeNa} \%$ & $1.13 \pm 0.98$ & $1.48 \pm 1.38$ & $2.84 \pm 3.10$ & $1.27 \pm 1.45$ & $4.01 \pm 5.90^{\mathrm{c}}$ & $5.65 \pm 6.81^{d}$ \\
\hline $\begin{array}{l}\mathrm{Cr}=\text { serum creatinine } \mathrm{cc} \\
\text { microglobulin; } \mathrm{RBP}=\mathrm{re} \\
\text { glucosaminidase. }{ }^{\mathrm{a}} p<0.0 \\
\text { newborns. }{ }^{\mathrm{b}} p<0.05, \text { sta } \\
\text { newborns on day } 1 .{ }^{\mathrm{c}} p \\
\text { preterm newborns on day } \\
\text { diseased preterm newborns }\end{array}$ & $\begin{array}{l}\text { ncentration; I } \\
\text { inol binding } \\
\text {, statistical si } \\
\text { tistically sign } \\
0.05 \text {, statisti }\end{array}$ & $\begin{array}{l}\mathrm{gG}=\text { immuno } \\
\text { protein; LAP } \\
\text { nificant differe } \\
\text { ficant differen } \\
\text { ally significar }\end{array}$ & $\begin{array}{l}\text { globulin } \mathrm{G} ; \\
=\text { leucine-an } \\
\text { nce between } \\
\text { e between } 1 \\
\text { tifference }\end{array}$ & $\begin{array}{l}l_{1} \mathrm{M}=\alpha_{1} \text {-mic } \\
\text { inopeptidase; } \\
\text { ays } 1 \text { and } 3 \mathrm{w} \\
\text { ealthy preterm } \\
\text { etween health }\end{array}$ & $\begin{array}{l}\text { oglobulin; } \beta_{2} \mathrm{~N} \\
\text { NAG }=N \text {-ace } \\
\text { thin the same } \\
\text { and diseased } \\
\text { fullterm and }\end{array}$ & $\begin{array}{l}=\beta_{2^{-}} \\
\text {yl- } \beta-D- \\
\text { roup of } \\
\text { reterm } \\
\text { healthy } \\
\text { rm and }\end{array}$ \\
\hline
\end{tabular}

Lower levels of urinary $\alpha_{1} \mathrm{M}$ were demonstrated between healthy fullterms and preterm infants on day 1 of life, suggesting that proximal tubular reabsorption improves before birth. Data of day 3 comparison between both healthy and diseased preterm infants revealed a significant difference in urinary levels of $\alpha_{1} \mathrm{M}$ and $\mathrm{RBP}$, as well as urinary activity of NAG and FeNa indicating that an alteration in the proximal tubular reabsorption, in the proximal tubular structure and in distal reabsorption capacity may develop shortly after birth.

Results of glomerular function showed significantly higher levels of serum creatinine and urinary excretion of IgG between days 1 and 3 in diseased preterm infants and no difference was observed for creatinine serum concentration in healthy preterm and fullterm infants. The damage of glomeruli leads to an increase of the filtrated load of proteins, which could lead to destruction of the structure of the proximal tubules with loss of absorptive capacity [50].

Results of urinary IgG excretion on day 3 compared with day 1 in healthy fullterm and diseased preterm infants showed a significant decrease suggesting a very transient proteinuria, and its decrement could be due to improved renal blood flow within the first days of life. 
The finding that on day 1, urinary IgG levels are significantly higher in diseased preterm infants than in healthy fullterm infants could be due to alterations of the glomerular filter that occur because of the decrease of cardiac output with or without affecting absorptive tubular function in different pathological aspects of the nephron, especially in premature infants.

\subsection{Drug Metabolism in Neonates}

Drug metabolism is divided into two phases; phase I reactions include oxidation, reduction, hydrolysis and demethylation [51]. The most important group of enzymes involved in phase I are the cytochrome P-450 (CYP) isoenzymes. Phase II includes glucuronidation, sulfation, methylation and acetylation [51]. The ontogeny of drug metabolism has been reviewed by Alcorn and McNamara [20] and by Hines and McCarver [52]. CYP content in the fetal liver is about 30 to $60 \%$ the adult values [51]. Most of the information on the drug metabolism enzyme activities during development is obtained in vitro with mid-gestation human fetal tissues. CYP3A7 is the most abundant isoenzymes at birth with a subsequent decrease in CYP3A7 activity most prominent during the first year of life, whereas CYP3A4 and CYP2D6 are the major contributors to drug metabolism in adults [52]. With the exception of sulfotransferase (SULT1A3) which is well expressed in mid-gestational human tissues [53-55], glucuronosyl transferase [54,56,57], methyltransferase [58,59] and acetyl transferase [60] are little expressed in the mid-gestation human fetal tissues. Furosemide is metabolised into an acidic compound and is conjugated with glucuronic acid [61] and glucuronyl transferase is little developed in the mid-gestation human fetal liver [54,56] and kidney [54,57].

\section{Results}

This review reports 155 studies. Table 2 summarises the pharmacokinetic parameters of furosemide in neonates. In each section of this review, the literature is cited chronologically, the first articles are the most recent and the last articles are the oldest ones.

Table 2. Demographic data of infants and pharmacokinetic parameters of furosemide in neonates.

\begin{tabular}{|c|c|c|c|c|c|c|c|c|c|}
\hline Population & $\begin{array}{c}\text { GA } \\
\text { (weeks) }\end{array}$ & $\begin{array}{l}\text { PNA } \\
\text { (days) }\end{array}$ & BW (g) & $\mathbf{n}$ & $\begin{array}{c}\text { Daily dose } \\
\text { (mg/kg) }\end{array}$ & $\mathbf{t}_{1 / 2}(h)$ & Vd (L/kg) & $\begin{array}{c}\mathrm{Cl} \\
(\mathrm{mL} / \mathrm{h} / \mathrm{kg}) \\
\end{array}$ & Ref. \\
\hline Fullterm & $34.0 \pm 4.7$ & $14.5 \pm 11.1$ & $2050 \pm 794$ & 6 & $1 \mathrm{IV}$ & $9.5 \pm 4.4$ & $0.17 \pm 0.03$ & $15.4 \pm 8.4$ & {$[62]$} \\
\hline Preterm & $29.0 \pm 2.0$ & $22.0 \pm 26.0$ & $1326 \pm 652$ & 8 & $\begin{array}{c}0.91 \pm 0.34 * \\
\text { IV }\end{array}$ & $\begin{array}{c}26.8 \pm \\
12.2\end{array}$ & $0.20 \pm 0.07$ & $6.9 \pm 5.1$ & \multirow{2}{*}[63]{} \\
\hline Fullterm & $39.0 \pm 1.0$ & $6.0 \pm 6.0$ & $2432 \pm 786$ & 7 & $\begin{array}{c}1.03 \pm 0.06 * \\
\text { IV }\end{array}$ & $13.4 \pm 8.6$ & $0.52 \pm 0.42$ & $11.8 \pm 9.3$ & \\
\hline${ }^{\mathrm{a}}$ Preterm & $30.0 \pm 0.8$ & $8.5 \pm 1.9$ & $1270 \pm 169$ & 14 & $1 \mathrm{IV}$ & $19.9 \pm 3.0$ & $0.24 \pm 0.03$ & $10.8 \pm 7.2$ & \multirow{2}{*}[64]{} \\
\hline Fullterm & na & 1-4 months & na & 12 & $1 \mathrm{IV}$ & $7.7 \pm 3.0$ & $0.83 \pm 0.01$ & $81.6 \pm 15.0$ & \\
\hline${ }^{\mathrm{a}}$ Fullterm & $35.0 \pm 1.8$ & $11.5 \pm 5.9$ & $2391 \pm 290 a$ & 8 & 1 to $1.5 \mathrm{IV}$ & $7.7 \pm 1.0$ & $0.81 \pm 0.12$ & $81.6 \pm 15.0$ & {$[65]$} \\
\hline Adults & & & & & & $1.3 \pm 0.8$ & $0.13 \pm 0.06$ & $99.6 \pm 34.8$ & [5] \\
\hline
\end{tabular}

Figures are the mean $\pm \mathrm{SD}$ unless otherwise stated; ${ }^{*} p<0.05 ;{ }^{a}$ Figures are the mean $\pm \mathrm{SE}$; na $=$ not available; IV = intravenously. 


\subsection{Dose of Furosemide in Neonates}

Initial dose of furosemide is $1 \mathrm{mg} / \mathrm{kg}$ intravenously with slow push, or intramuscularly. The dose may increase to a maximum of $2 \mathrm{mg} / \mathrm{kg}$ per dose intravenously or $6 \mathrm{mg} / \mathrm{kg}$ per dose orally [7]. In premature infants administrate furosemide every $24 \mathrm{~h}$, whereas in fullterm infants administrate furosemide every $12 \mathrm{~h}$ [7]. Neonatal Formulary [10] suggests giving $1 \mathrm{mg} / \mathrm{kg}$ of furosemide intravenously or intramuscularly, or $2 \mathrm{mg} / \mathrm{kg}$ by mouth, repeatable after 12 to $24 \mathrm{~h}$. The drug should not be given more than once every $24 \mathrm{~h}$ to infants with postmenstrual age of less than 31 weeks. Patients on long-term treatment with furosemide may require $1 \mathrm{mmol} / \mathrm{kg}$ per day of oral potassium chloride to prevent hypokalemia [10]. It has been suggested to giving a single $5 \mathrm{mg} / \mathrm{kg}$ furosemide intravenously for renal failure as soon as renal failure is suspected to lower the metabolic activity of the chloride pump, minimise the risk of ischemic tubular damage, and reduce the shut down in glomerular blood flow that follows from this [10]. For chronic lung disease give $1 \mathrm{mg} / \mathrm{kg}$ furosemide by nebuliser once every $6 \mathrm{~h}$ which may at least temporarily improve lung compliance and therefore tidal volume in some ventilator-dependent infants without affecting renal function [10].

\subsection{Renal Response to Furosemide in Neonates}

The response to furosemide can be evaluated by studying the dose response relationship between the logarithm of the urinary furosemide excretion rate and diuretic/natriuretic response [66]. Mirochnick et al. [67] observed a relationship between the logarithm of the urinary furosemide excretion rate and both the urinary and sodium excretion rate and urine output following initial and chronic multiple doses. There was a significant increase in the mean furosemide excretion rate associated with the midrange responses after 1 and 3 weeks of therapy compared with the initial dose. The urinary excretion of furosemide was $219 \pm 130$ (week 1), $959 \pm 381$ (week 2) and $738 \pm 323 \mu \mathrm{g} / \mathrm{kg} / 12 \mathrm{~h}$ (week 3) [67].

\subsection{Metabolism of Furosemide in Neonates}

The metabolism of furosemide in neonates was studied by Aranda et al. [61]. Furosemide is metabolised into an inactive acidic metabolite (2-amino-4-chloro-5-sulfamoyl anthranilic acid) and is conjugated with glucuronic acid to give inactive furosemide glucuronide. Following a $1 \mathrm{mg} / \mathrm{kg}$ intravenous dose of furosemide in newborn infants, the most rapid excretion of furosemide and its metabolites occurred during the first six hours after the dose. Mean fractions of the total urinary excretion as unchanged furosemide ranged between 52.5 and $55.6 \%$ [61]. The mean fractions of total urinary excretion as furosemide glucuronide and acidic metabolite ranged from 13.3 to $23.2 \%$ and from 20.9 to $29.3 \%$, respectively [61]. An inverse relationship was observed between the urinary excretion of the acidic metabolite $(\mathrm{r}=-0.75 ; p<0.05)$ and the excretion of unchanged furosemide and the excretion of furosemide glucuronide $(\mathrm{r}=-0.76 ; p<0.05)$ and the excretion of unchanged furosemide.

\subsection{Binding of Furosemide to Neonatal Plasma Proteins}

To evoke a pharmacological effect, the drugs must leave the blood, accumulate into the tissues and bind to their receptors. In blood, drugs are bound to plasma proteins and only the unbound 
fraction (free fraction) may leave the blood and penetrate into the tissues. The main plasma proteins binding the drugs are albumin and $\alpha$-1-acid glycoprotein [68]. Furosemide binds to albumin [69,70]. Variations in the concentration of plasma albumin yield variations in the concentrations of the unbound fraction of drugs with consequent variations in the amounts of drugs that penetrate into the tissues. In the umbilical cord plasma, the concentration of albumin ranged from 24.6 to $57.3 \mathrm{~g} / \mathrm{L}$ (mean $\pm \mathrm{SD}=42.7 \pm 6.5 \mathrm{~g} / \mathrm{L} ; \mathrm{n}=56$ ), the coefficient of variation was $15 \%$ [71]. In adults, the concentration of albumin was $50.4 \pm 6.0 \mathrm{~g} / \mathrm{L}(\mathrm{n}=31$; age $34 \pm 6$ years $)$ and was significantly $(p<0.001)$ greater than that in the cord plasma [71]). The unbound fraction of furosemide in the umbilical cord plasma was $2.5 \pm 0.1$ and in adult plasma was $1.7 \pm 0.7(p<0.001 ;[72])$.

The serum concentration of albumin was measured in 13 children, aged from birth to 8 months of age, and a correlation $(\mathrm{r}=0.763 ; p<0.001)$ was found between the serum concentration of albumin and the child age [72]. The unbound fraction of furosemide was measured in the plasma of 51 children aged between 2 weeks and 13.5 years. The unbound fraction of furosemide decreased gradually from birth, approaching the adult values within the first year of life. There was a significant correlation $(p<0.001)$ between the percentage of unbound fraction of furosemide and the first six months of life [72].

Bilirubin displaces furosemide from albumin and the effect is greater in newborn infants than in adult subjects $[73,74]$. The unbound fraction of furosemide in the plasma of newborn infants was $2.32 \pm 0.14,2.94 \pm 0.26$ and $3.52 \pm 0.38$ in the absence, and in presence of $200 \mu \mathrm{M}$ and $400 \mu \mathrm{M}$ bilirubin, respectively [73]. The unbound fraction of furosemide was significantly greater in the plasma to which bilirubin was added $(p<0.001)$. The dialysis of the cord serum increased the binding of furosemide suggesting that the cord serum contains dialyzable compounds that interfere with the binding of furosemide [75]. The binding defect of furosemide in newborn plasma reflects both the effects of the endogenous inhibitors and the lower albumin concentration.

\subsection{Pharmacokinetics of Furosemide in Neonates}

Administered drugs are eliminated from the body, and the rate of drug elimination determines the concentrations of drugs in plasma and tissues. Elimination of a drug consists in two processes, metabolism and renal excretion. $\mathrm{t}_{1 / 2}$ is the time that a drug requires to halve its concentration. $\mathrm{Vd}$ is the apparent volume into which a drug distributes in the body at equilibrium and is an index of drug accumulation into solid tissues. $\mathrm{Cl}$ is the product of the constant of elimination (Ke) multiplied by $\mathrm{Vd}$. $\mathrm{Ke}=0.693 / \mathrm{t}_{1 / 2}$, thus, $\mathrm{Cl}=\mathrm{Vd} \times 0.693 / \mathrm{t}_{1 / 2}$. As $\mathrm{t}_{1 / 2}$ shortens $\mathrm{Cl}$ increases, postnatal maturation shortens $\mathrm{t}_{1 / 2}$ and increases $\mathrm{Cl}$.

The pharmacokinetics of furosemide in neonates consists in 5 articles [6,62-65] published between 1978 and 1988. The pharmacokinetic parameters of furosemide in the newborn infants are summarised in table 2. In adults, $\mathrm{t}_{1 / 2}, \mathrm{Cl}$ and $\mathrm{Vd}$ of furosemide are $1.3 \pm 0.8 \mathrm{~h}, 99.6 \pm 34.8 \mathrm{~mL} / \mathrm{h} / \mathrm{kg}$ and $0.13 \pm 0.06$ $\mathrm{L} / \mathrm{kg}$, respectively [5]. In infants, $\mathrm{t}_{1 / 2}$ is 6 to 20 -fold longer, $\mathrm{Cl}$ is 1.2 to 14 -fold smaller and $\mathrm{Vd}$ is 1.3 to 6 -fold larger than the adult values. This body of knowledge is consistent with the view that the elimination of furosemide is remarkably slower and variable in neonates than in adults and is associated with its prolonged diuretic and saliuretic effects [76,77].

The reason for prolonged $t_{1 / 2}$ of furosemide in newborn infants is the slow renal excretion, related to immature renal function, which is compounded by reduced metabolic elimination. The kidney 
maturation drives furosemide pharmacokinetics. The capacity for non-renal elimination of furosemide must be presumed to develop at some time between birth and adulthood [62]. Aranda et al. [61] obtained different results, they observed that furosemide is metabolised in neonates. These authors found that furosemide is conjugated with glucuronic acid and the acidic metabolite 2-amino-4-chloro5-sulfamoyl anthranilic acid is formed. At $6 \mathrm{~h}$ after administration, the urinary fractions of the parent compound, the glucuronide conjugate and the acidic metabolite were $55.4 \pm 5.5 \%, 23.3 \pm 5.5 \%$ and $21.2 \pm 8.3 \%$, respectively [61].

The postnatal development of furosemide pharmacokinetics was studied by Mirochnick et al. [6]. These authors administered $1 \mathrm{mg} / \mathrm{kg}$ furosemide intravenously to 10 preterm infants with a gestational age, a postnatal age and a body weight of $26.6 \pm 2.9$ weeks, $2.4 \pm 1.0$ days and $829 \pm 217 \mathrm{~g}$, respectively. Subsequent doses of either $1 \mathrm{mg} / \mathrm{kg}$ administered intravenously, or $2 \mathrm{mg} / \mathrm{kg}$ administered enterally, were given every $12 \mathrm{~h}$ to the first seven patients and every $24 \mathrm{~h}$ to the last three patients. Plasma $\mathrm{t}_{1 / 2}$ ranged from 1.8 to $63 \mathrm{~h}$ and was longest in the most immature infants. Patients $<31$ weeks postmenstrual age frequently had $t_{1 / 2}$ in excess of $24 \mathrm{~h}$. By 33 weeks postmenstrual age, $\mathrm{t}_{1 / 2}$ had declined to less than $12 \mathrm{~h}$ in all infants. As postmenstrual age approached term, $\mathrm{t}_{1 / 2}$ declined to approximately $4 \mathrm{~h}$. There was a remarkable interindividual variability in the kinetic parameters of furosemide in neonates. Plasma $t_{1 / 2}$ of furosemide was measured in 14 preterm infants and a poor, but significant inverse correlation $(\mathrm{r}=-0.360)$, was found with postmenstrual age and postnatal age $(\mathrm{r}=-0.482)$ whereas it did not correlate with gestational age or birthweight [64]. These authors found a correlation between $\mathrm{Cl}$ and postnatal age $(\mathrm{r}=0.79)$.

Renal $\mathrm{Cl}$ of furosemide ranged from 1.62 to $73.8 \mathrm{~mL} / \mathrm{h} / \mathrm{kg}$ and was lowest in the most immature infants [6]. Renal $\mathrm{Cl}$ increased gradually until 32 weeks postmenstrual age; after 32 weeks, renal $\mathrm{Cl}$ increased rapidly. The fraction of total renal $\mathrm{Cl}$ due to tubular secretion was small when $\mathrm{t}_{1 / 2}$ was prolonged. When $\mathrm{t}_{1 / 2}$ was $>24 \mathrm{~h}$, tubular secretion accounted for $13.3 \pm 19.2 \%$ of total $\mathrm{Cl}$. When $\mathrm{t}_{1 / 2}$ was $<12 \mathrm{~h}$, the secretory fraction increased to $83.7 \pm 9.3 \%$ [6]. When furosemide was administered every $12 \mathrm{~h}$, this drug accumulated in plasma and the highest concentration was $21.1 \mu \mathrm{g} / \mathrm{mL}$. There was an inverse significant correlation $(\mathrm{r}=-0.94 ; p<0.002)$ between postmenstrual age and maximum plasma concentration attained.

Bioavailability of furosemide was determined in 3 patients at a mean postmenstrual age of 39.1 weeks. Mean bioavailability was $84.3 \%$ (range $56 \%$ to $106 \%$ ) [6]. Mean Vd after the initial dose was $0.23 \pm 0.041 / \mathrm{kg}$. Although $\mathrm{Vd}$ did not change significantly during the first 2 weeks of therapy, it did increase over the course of the entire study. Three patients, $>6$ weeks after the initiation therapy, received a total of 4 intravenous doses of furosemide. Mean $\mathrm{Vd}$ increased to $0.48 \pm 0.14 \mathrm{1} / \mathrm{kg}$, a significant $(p=0.0003)$ increase compared with $\mathrm{Vd}$ after the initial dose. Vert et al. [63] and Peterson et al. [64] observed that Vd is larger in fullterm than in preterm infants. This suggests that, in fullterm infants, a greater fraction of the administered dose of furosemide is distributed in periphery.

Plasma $\mathrm{t}_{1 / 2}, \mathrm{Vd}$ and $\mathrm{Cl}$ showed considerable variation among infants, but plasma and urinary $\mathrm{t}_{1 / 2}$ corresponded very closely for each infant $(\mathrm{r}=0.97 ; p<0.005)$ [62]. There was also a correlation between plasma $\mathrm{Cl}$ and renal $\mathrm{Cl}(\mathrm{r}=0.96 ; p<0.005)$ [62]. Between 4 and $24 \mathrm{~h}$ after furosemide intravenous injection, renal $\mathrm{Cl}$ was estimated to account for a mean of $99 \%$ of total plasma $\mathrm{Cl}$. Twenty-four hours after administration, mean urinary recovery of unchanged furosemide was $90 \%$ of the injected dose. The renal $\mathrm{Cl}$ to plasma $\mathrm{Cl}$ ratio did appear to decrease with increasing postnatal age 
$(\mathrm{r}=-0.81 ; p<0.05 ;[62])$. These results indicate that the renal $\mathrm{Cl}$ of furosemide accounts for virtually all of total plasma $\mathrm{Cl}$ in newborn infants. These results do not accord with those by Aranda et al. [61] who found that furosemide is metabolised in preterm infants. Expressed as a proportion of the intravenous injected dose, total urinary furosemide recovered was (mean \pm SE) $89.7 \pm 15.2 \%$ [62] and $84.4 \pm 14.9 \%$ [65]. The urine elimination $\mathrm{t}_{1 / 2}$ of furosemide was measured in 13 infants, aged from 9 days to 12 months, and ranged from 0.654 to $3.29 \mathrm{~h}$ [78].

\subsection{Continuous versus Intermittent Intravenous Infusion of Furosemide in Neonates and Infants}

\section{Undergoing Cardiac surgery}

Appropriate maintenance of the patient's volume status is an important part of the perioperative management of patients undergoing cardiac surgery [79-81]. Patients often become volume overload after surgery, due in part to the large amounts of fluids received intra-operatively for cardiopulmonary bypass and hypotensive episodes [80]. If the hypervolemia is not corrected, it can contribute to the development of postoperative hypoxia, tissue edema, and delayed postoperative recovery [80,81]. One of the mainstays for postoperative fluid overload is the administration of furosemide [79].

The efficacy of a continuous intravenous infusion of furosemide in pediatric patients following cardiac surgery was first investigated by Singh et al. [82]. Infants were randomized to receive a continuous intravenous infusion or intermittent intravenous bolus doses of furosemide. The continuous intravenous infusion group received an intravenous initial furosemide dose of $0.1 \mathrm{mg} / \mathrm{kg}$ followed by an infusion rate of $0.1 \mathrm{mg} / \mathrm{kg} / \mathrm{h}$ of furosemide to be doubled every $2 \mathrm{~h}$ to a maximum of $0.4 \mathrm{mg} / \mathrm{kg} / \mathrm{h}$ if the urine output was less than $1 \mathrm{~mL} / \mathrm{kg} / \mathrm{h}$.

The intermittent group received $1 \mathrm{mg} / \mathrm{kg}$ of furosemide intravenously every $4 \mathrm{~h}$ to be increased by $0.25 \mathrm{mg} / \mathrm{kg}$ every $4 \mathrm{~h}$ to a maximum of $1.5 \mathrm{mg} / \mathrm{kg}$ intravenously if the urine output was less than $1 \mathrm{~mL} / \mathrm{kg} / \mathrm{h}$. The results of the trial showed no significant difference in urinary output between the 2 groups over $24 \mathrm{~h}$ period. A significantly $(p=0.045)$ lower daily dose of furosemide $(4.90 \pm 1.78$ versus $6.23 \pm 0.62 \mathrm{mg} / \mathrm{kg} /$ day) in the continuous intravenous infusion group produced the same 24-hour urine volume as that of the intermittent group. There was more variability in urine output in the intermittent group as well as more urinary losses of sodium $(0.29 \pm 0.15$ versus $0.020 \pm 0.06$ $\mathrm{mmol} / \mathrm{kg} / \mathrm{day} ; p=0.007)$, and chloride $(0.40 \pm 0.20$ versus $0.30 \pm 0.12 \mathrm{mmol} / \mathrm{kg} / \mathrm{day} ; p=0.045)$.

Three cases of supraventricular tachycardia, associated with the use of furosemide infusion following cardiac surgery, were reported by Wilson et al. [83]. The supraventricular tachycardia occurred 3 to $7 \mathrm{~h}$ after starting an intravenous infusion of furosemide at $1.0 \mathrm{mg} / \mathrm{kg} / \mathrm{h}$. All three patients had a diuresis of 8 to $10 \mathrm{~mL} / \mathrm{kg} / \mathrm{h}$ compared with a mean average of $2.5 \mathrm{~mL} / \mathrm{kg} / \mathrm{h}$ in 22 other patients who had received a similar infusion. A rapid fluid shift was the most likely mechanism of the tachycardia. Sotalol was effective in controlling the tachycardia in the two patients in whom it was tried. These authors recommend a starting dose of $0.3 \mathrm{mg} / \mathrm{kg} / \mathrm{h}$ in infusing intravenously furosemide, with hourly increments of $0.1 \mathrm{mg} / \mathrm{kg} / \mathrm{h}$ until the desired diuresis have been obtained.

Luciani et al. [84] compared the safety and efficacy of continuous versus intermittent intravenous furosemide. Continuous infusion of furosemide was administered to 11 infants with an age and a body weight of $3.7 \pm 3.4$ months and $4.6 \pm 2.1 \mathrm{~kg}$, respectively. The patients were given an initial dose of $0.1 \mathrm{mg} / \mathrm{kg}$ intravenous furosemide and then continuous infusion was started at $0.1 \mathrm{mg} / \mathrm{kg} / \mathrm{h}$. 
This infusion rate was doubled every $2 \mathrm{~h}$ (to a maximum of $0.4 \mathrm{mg} / \mathrm{kg} / \mathrm{h}$ ) if the urinary output was less than $1 \mathrm{~mL} / \mathrm{kg} / \mathrm{h}$ in the 4 previous hours of observation. Intermittent furosemide was administered to 15 infants with an age and a body weight of $1.8 \pm 2.5$ months and $4.3 \pm 1.7 \mathrm{~kg}$, respectively. The patients were given $1 \mathrm{mg} / \mathrm{kg}$ of furosemide intravenously every $4 \mathrm{~h}$. The dose was increased by $0.25 \mathrm{mg} / \mathrm{kg}$, to a maximum of $2 \mathrm{mg} / \mathrm{kg}$ intravenously, if the urine output was less than $1 \mathrm{~mL} / \mathrm{kg} / \mathrm{h}$ in the previous $4 \mathrm{~h}$ of observation. The efficacy of furosemide in terms of urinary output was satisfactory in both patient groups. When the urinary volume was corrected for the dose of drug administered, a significantly larger response could be demonstrated with continuous intravenous infusion. The dose of furosemide administered was $2.5 \pm 0.3$ (continuous infusion) and $6.8 \pm 12 \mathrm{mg} / \mathrm{kg} / \mathrm{day}$ (intermittent infusion; $p=0.001)$. Urinary output per dose of drug was significantly larger after continuous intravenous infusion $(1.0 \pm 0.4 \mathrm{~mL} / \mathrm{kg} / \mathrm{h})$ than after intermittent intravenous furosemide $(0.5 \pm 0.2 \mathrm{~mL} / \mathrm{kg} / \mathrm{h}$; $p=0.002$ ) with lesser fluctuations (variance, $1.9 \pm 1.6$ versus $3.8 \pm 2.1 ; \mathrm{p}=0.02$ ) and fluid replacement needs $(20.6 \pm 3.8$ versus $51.8 \pm 14.4 ; \mathrm{p}=0.0017)$. Luciani et al. [84] conclude that commonly used doses of both intermittent and continuous furosemide infusion can be safely administered to critically ill neonates and infants as early as $6 \mathrm{~h}$ after operation.

Intermittent intravenous therapy with furosemide may cause unpredictable fluctuations in the serum concentrations of the drug, thereby exposing the patients to the risk of ototoxicity and nephrotoxicity $[85,86]$.

There are a number of critically ill infants in whom diuretic response to conventional furosemide administration may be suboptimal or even absent. These patients are generally considered "diuretic resistant" [66].

In a study by Copeland et al. [87] on 18 adult patients who were hemodynamically stable after cardiac surgery, no significant difference was demonstrated in terms of urinary output between continuous intravenous infusion and intermittent intravenous administration of furosemide. Continuous intravenous infusion, however, offered a more constant urinary flow.

Klinge et al. [88] compared the urine output in 46 children undergoing cardiac surgery following intermittent intravenous or continuous intravenous administration. Twenty-three children aged $2.4 \pm$ 2.1 years with a body weight of $10.8 \pm 5.7 \mathrm{~kg}$ received intermittent intravenous furosemide and other 23 infants aged $3.4 \pm 3.1$ years with a body weight $14.5 \pm 9.3 \mathrm{~kg}$ received continuous intravenous infusion of furosemide. The initial dose of intermittent intravenous furosemide was $0.5 \mathrm{mg} / \mathrm{kg}$ per day, and the initial dose of continuous intravenous infusion of furosemide was $2 \mathrm{mg} / \mathrm{kg}$ per day. The patients in the intermittent group needed a significantly lower daily dose of furosemide.

When the dose of furosemide was adjusted to the patient's need, instead of administering in a fixed dose as it had been in the studies by Copeland et al. [87], van Meyel et al. [89] and Lahav et al. [90], intermittent intravenous administration of furosemide resulted in a significantly lower daily dose of furosemide over the study period of 3 days and the dose was significantly more effective.

Vanpeè et al. [91] observed that the development of glomerular and tubular renal function is delayed in preterm infants. van der Vorst et al. [92] evaluated the pharmacokinetics and effects of continuous intravenous furosemide in hemodynamically unstable pediatric patients after cardiac surgery. Nineteen infants with a median age of 13 weeks (range 0 to 33 weeks) and a body weight of $4.2 \mathrm{~kg}$ (range 3.0 to $6.6 \mathrm{~kg}$ ) requiring a 3-day treatment of continuous intravenous infusion of furosemide were enrolled in the study. Ten patients received one or more furosemide boluses (mean $\pm \mathrm{SD}$, 
$1.4 \pm 1.1)$ and the bolus doses had a mean of $1.3 \pm 0.4 \mathrm{mg} / \mathrm{kg}$. The furosemide intravenous infusions were started at a median time of $30 \mathrm{~h}$ after cardiac surgery with a rate of $0.1 \mathrm{mg} / \mathrm{kg} / \mathrm{h}$. The median urinary furosemide excretion rate at the end of day 1,2 and 3 was $0.45,0.70 \mathrm{mg} / \mathrm{h}$, and $0.69 \mathrm{mg} / \mathrm{h}$, respectively. The median urinary sodium excretion was $2.1,9.4$, and $11.5 \mathrm{mmol} / \mathrm{kg}$ per $24 \mathrm{~h}$ over days 1,2 and 3, respectively. The median urinary output was $2.4,5.8$, and $5.4 \mathrm{~mL} / \mathrm{kg} / \mathrm{h}$ over the respective treatment days.

Continuous intravenous infusion of furosemide is superior to intermittent infusion of furosemide, because continuous intravenous administration results in a more controlled diuresis $[82,84,88,93]$. van der Vorst et al. [93] studied 15 infants with a median of 12 weeks (range 0.2 to 35 weeks) and the weight was $4.0 \mathrm{~kg}$ (range 3.0 to $6.2 \mathrm{~kg}$ ) undergoing cardiopulmonary bypass surgery who were hemodynamically unstable and in whom transient renal insufficiency occurred. At the start of the study, nine patients were diagnosed with acute renal failure. The total dose of furosemide boluses administered to the infants before the start of the continuous infusion was $2.94 \pm 1.08 \mathrm{mg} / \mathrm{kg}$. Continuous intravenous infusion of furosemide was started at a median time $25 \mathrm{~h}$ (range 14 to $34 \mathrm{~h}$ ) postoperatively. The mean continuous intravenous furosemide dose was $0.22 \pm 0.06,0.25 \pm 0.10$ and $0.22 \pm 0.11 \mathrm{mg} / \mathrm{kg} / \mathrm{h}$ on the first, second and third day, respectively. There was a strong linear relationship between sodium excretion and urine production, with correlation coefficients ranging from 0.66 to 0.99 ( $\mathrm{p}$ ranged from 0.02 to 0.0003 ). With increasing urinary furosemide excretion, higher values of sodium excretion and urine output were observed, with no indication of tolerance.

Van der Vorst et al. [94] stated that tolerance of furosemide effect does not develop with prolonged diuretic exposure. It has been suggested that the tolerance to furosemide can be induced through different but complementary homeostatic mechanisms in the kidney $[95,96]$. The mechanism underlies the development of tolerance is dehydration. This provides a possible explanation as to why tolerance was not observed in the patients, because they were volume overloaded and certainly not dehydrated at any time during the continuous furosemide infusion. There are no indications that tolerance develops towards the diuretic effect of furosemide in hemodynamically unstable infants with volume overload after cardiac surgery with cardiopulmonary bypass, who are treated with a relatively aggressive diuretic regimen with furosemide. It is unlikely that the high furosemide dose was associated with renal toxicity [94]. Relatively high furosemide doses did not result in metabolic alkalosis. These authors conclude that the employed furosemide regimen can be used safely in haemodynamically unstable infants after cardiac surgery.

\subsection{Furosemide in Neonates and Infants Treated with Extracorporeal Membrane Oxygenation}

Extracorporeal membrane oxygenation (ECMO) is a modified heart-lung machine combined with a membrane oxygenator to provide cardiopulmonary support for patients with reversible pulmonary failure in whom conventional therapies failed [97]. A 20-year experience on neonatal ECMO was reported by Schaible et al. [8]. Randomized studies showed improved survival for neonates treated with ECMO in comparison with conventional treatment [98,99]. During the period 1987 to 2006, 321 newborns with respiratory failure were treated with ECMO [8]. Mean gestational age was 38.7 weeks, and mean birthweight was $3163 \mathrm{~g}$. diaphragmatic hernia was the most common diagnosis (53\%), followed by meconium aspiration syndrome (21\%), sepsis and/or pneumonia (13\%) and others (13\%). 
Van der Vorst et al. [100] explored a continuous intravenous furosemide regimen that adapts to urine output in neonates treated with ECMO. Seven neonates admitted to a pediatric surgical intensive care unit for ECMO therapy, younger than 1 year of age, were enrolled in the study. The continuous intravenous furosemide infusion was started at a rate of $0.2 \mathrm{mg} / \mathrm{kg} / \mathrm{h}$ and was preceded by a loading bolus of $1 \mathrm{mg} / \mathrm{kg}$ in patients with normal renal function and $2 \mathrm{mg} / \mathrm{kg}$ in patients with acute renal failure. The aim was to reach and maintain a urine output of $6 \mathrm{~mL} / \mathrm{kg} / \mathrm{h}$.

The volume of ECMO circuit was approximately $400 \mathrm{~mL}$, and the solution consisted of albumin and packed red blood cells. The mean \pm SD of furosemide dose was $0.17 \pm 0.06 \mathrm{mg} / \mathrm{kg} / \mathrm{h}, 0.08 \pm 0.04$ $\mathrm{mg} / \mathrm{kg} / \mathrm{h}$, and $0.12 \pm 0.07 \mathrm{mg} / \mathrm{kg} / \mathrm{h}$, respectively, over the first, second and third day of the study. Furosemide $\mathrm{Vd}$ was $0.51 / \mathrm{kg}$ (range 0.2 to $2.7 \mathrm{l} / \mathrm{kg}$ ). Furosemide concentration, $10 \mathrm{~min}$ after the loading bolus, was $1.95 \mu \mathrm{g} / \mathrm{mL}$ (range 0.4 to $4.7 \mu \mathrm{g} / \mathrm{mL}$ ), and the concentration in all of the samples $(\mathrm{n}=15)$ taken during the entire observation period was $3.1 \mu \mathrm{g} / \mathrm{mL}$ (range 0.4 to $12.9 \mu \mathrm{g} / \mathrm{mL}$ ).

Urine production from the start of ECMO until the start of furosemide therapy was $2.2 \mathrm{~mL} / \mathrm{kg} / \mathrm{h}$, and increased to $7.9 \mathrm{~mL} / \mathrm{kg} / \mathrm{h}$ and $6.1 \mathrm{~mL} / \mathrm{kg} / \mathrm{h}$ after 8 and $16 \mathrm{~h}$, respectively, of continuous intravenous furosemide infusion. The median urine production over the consecutive 3 days was $6.8 \mathrm{~mL} / \mathrm{kg} / \mathrm{h}$, $6.0 \mathrm{~mL} / \mathrm{kg} / \mathrm{h}$, and $5.4 \mathrm{~mL} / \mathrm{kg} / \mathrm{h}$. The target urine production was reached after a median time of $7 \mathrm{~h}$ ( 3 to $37 \mathrm{~h}$ ). Followed by a continuous infusion at $0.2 \mathrm{mg} / \mathrm{kg} / \mathrm{h}$, which was adjusted according to the target urine production of $6 \mathrm{~mL} / \mathrm{kg} / \mathrm{h}$, the mean $\pm \mathrm{SD}$ furosemide dose was $0.17 \pm 0.06 \mathrm{mg} / \mathrm{kg} / \mathrm{h}, 0.08 \pm 0.04 \mathrm{mg} / \mathrm{kg} / \mathrm{h}$ and $0.12 \pm 0.07 \mathrm{mg} / \mathrm{kg} / \mathrm{h}$, respectively, on the first day, second day and third day of the study. The median urine production over the consecutive study days was $6.8 \mathrm{~mL} / \mathrm{kg} / \mathrm{h}, 6.0 \mathrm{~mL} / \mathrm{kg} / \mathrm{h}$ and $5.4 \mathrm{~mL} / \mathrm{kg} / \mathrm{h}$ [100]. The regimen was hemodynamically well tolerated and the median furosemide serum concentrations were $3.1 \mu \mathrm{g} / \mathrm{mL}$, well below the toxic level. Furosemide infusion appears an effective means to reduce volume overload in neonates treated with ECMO.

Van der Vorst et al. [9] evaluated the furosemide regimen in neonates treated with ECMO. Thirtyone infants with a mean gestational age of 40 weeks and a mean postnatal age of 1 day (range 0 to 16 days) and median body weight of $3.5 \mathrm{~kg}$ were enrolled in the study. Prior to the start of continuous intravenous infusion of furosemide, seven patients received an intravenous furosemide bolus (0.4 to $2.4 \mathrm{mg} / \mathrm{kg}$ ). The continuous intravenous furosemide dose, in the patients who received a bolus prior to the infusion, was $0.08 \mathrm{mg} / \mathrm{kg} / \mathrm{h}$ (range 0.04 to $0.13 \mathrm{mg} / \mathrm{kg} / \mathrm{h}$ ); in the patients who did not receive a bolus, the dose was $0.08 \mathrm{mg} / \mathrm{kg} / \mathrm{h}$ (range 0.02 to $0.17 \mathrm{mg} / \mathrm{kg} / \mathrm{h}$ ) $\mathrm{mg} / \mathrm{kg} / \mathrm{h}$. Mean urine production remained $6.2 \mathrm{~mL} / \mathrm{kg}$ per $24 \mathrm{~h}$ of continuous infusion of furosemide in all patients irrespective of a bolus prior to the continuous furosemide infusion.

The dosing schedule of continuous intravenous infusion of furosemide in neonates treated with ECMO is largely empirical because of the variable renal function and the altered furosemide pharmacokinetics. van der Vorst et al [9] observed that the dose of the continuous intravenous infusion of furosemide varied from 0.02 to $0.17 \mathrm{mg} / \mathrm{kg} / \mathrm{h}$, and that $39 \%$ of the patients received additional diuretic. Although the urine output was satisfactory in patients studied, the use of additional diuretic suggests that the applied infusion rates were not optimal.

The limited studies conducted in infants receiving ECMO have identified significant differences in pharmacokinetic parameters. These differences arise from a complex interplay of changes in physiology resulting from the addition of ECMO circuit, the patient's underlying dynamic disease process, and the alteration caused by disruptions in blood flow and drug binding to the circuit [101]. 
Furosemide was substantially adsorbed onto ECMO circuits components. Analysis of four ECMO circuits into which doses of 5 and $10 \mathrm{mg}$ furosemide were injected revealed a 63 to $87 \%$ reduction in serum furosemide concentrations measured over 4-hour observation period. This loss of drug was most pronounced within the first 30 min of distribution through the circuit [101].

\subsection{Inhaled Furosemide in Preterm Infants}

Kugelman et al. [102] hypothesized that inhaled furosemide will result in improved pulmonary mechanics in ventilated infants with bronchopulmonary dysplasia and will prevent the systemic complications of parenteral furosemide. A randomized, double-blind, crossover study was performed on 9 infants with bronchopulmonary dysplasia, each serving as his own control. The infant gestational age was $29 \pm 1$ weeks, the birthweight was $1100 \pm 100 \mathrm{~g}$, the age at study was $47 \pm 6$ days, and weight at study was $1800 \pm 200 \mathrm{~g}$. Each patient was randomized to receive an aerosol dose of furosemide ( $1 \mathrm{mg} / \mathrm{kg}$ in $2 \mathrm{~mL}$ of saline) or placebo ( $2 \mathrm{~mL}$ of saline). Pulmonary mechanics were measured before and 1 and $2 \mathrm{~h}$ after the inhalation using the "Pulmonary Evaluation and Diagnostic System". There was no significant change in dynamic compliance, dynamic resistance, and tidal volume 1 or $2 \mathrm{~h}$ after treatment with either furosemide or placebo. Kugelman et al. [102] concluded that, under the conditions of study, a single dose of $1 \mathrm{mg} / \mathrm{kg}$ inhaled furosemide does not improve the pulmonary mechanics in ventilator-dependent infants with severe bronchopulmonary dysplasia.

Bar et al. [103] evaluated the short- and long-term effects and the treatment feasibility of inhaled furosemide as compared with placebo via hood in hospitalised infants with viral-bronchiolitis. A randomised, double-blind, placebo-controlled study was performed with 16 infants in each group; postnatal age was $72 \pm 43$ days. Enrolled infants were randomized to receive either inhaled-furosemide $(2 \mathrm{mg} / \mathrm{kg}$ ), or placebo nebulised by hood three times daily throughout the hospitalisation. Clinical assessment (Respiratory Distress Assessment Instrument) was performed, 30 and 60 min after the first daily inhalation. The short-term effects were evaluated by "respiratory distress assessment instrument", and the long-term effects by time to be weaned off oxygen, time to full enterally feeding, length of stay, and "ready to discharge" time. Oxygen requirement decreased significantly at 30 min post-inhalation only in the inhaled furosemide group. Respiratory assessment change score and long-term effects of both groups were comparable. These results showed that inhaled furosemide has no significant clinical effects in hospitalized infants with viral-bronchiolitis.

Prabhu et al. [104] compared the effects of a single dose of furosemide (1 mg/kg) administered either intravenously or by nebulisation on pulmonary mechanics in 19 premature infants, at 24 to 30 weeks of gestational age, evolving chronic lung disease. The infant mean postnatal age was 23 days (range 14 to 52 days). Infants had been dependent on mechanical ventilation since birth. Furosemide was administered, in random order, intravenously and by nebulisation, on two separate occasions $24 \mathrm{~h}$ apart. Pulmonary function studies were performed before and at 30,60 and 120 min after administration of furosemide. Nebulised furosemide increased the tidal volume $31 \pm 11.5 \%$ and compliance $34 \pm 12 \%$ after two hours, whereas no change in either was noted for up to two hours after intravenous furosemide administration. Neither intravenous nor nebulised furosemide had any effect on airway resistance. Prabhu et al. [104] conclude that a single dose of nebulised furosemide improves pulmonary function in premature infants with evolving chronic lung disease. 
Ohki et al. [105] investigated whether aerosolized furosemide would improve pulmonary function in infants with chronic lung disease. Eight preterm ventilator-dependent infants were enrolled in a cross-over, double-blind, placebo-controlled study. Either aerosolized furosemide (2 $\mathrm{mg} / \mathrm{kg}) \mathrm{or}$ placebo $(0.9 \%$ saline $)$ was administered, and serial pulmonary function tests were performed before and at 1 and $2 \mathrm{~h}$ after each inhalation. After furosemide inhalation, static respiratory compliance increased significantly by $24.3 \%$ and $23.2 \%$ as percentage change from the baseline value at 1 and $2 \mathrm{~h}$ ( $p=0.014$ and 0.022 , respectively). Also tidal volume increased significantly by $33.8 \%$ and $28.7 \%$ at 1 and $2 \mathrm{~h}$, respectively ( $p=0.004$ and 0.009 ). In contrast, no changes were observed in the infants after placebo inhalation. Total respiratory resistance was unchanged after both furosemide and placebo inhalation. These data suggest that aerosolized furosemide improved pulmonary function in infants with chronic lung disease without excessive diuresis.

Rastogi et al. [106] studied the effects of different doses of nebulised furosemide on 8 preterm infants with bronchopulmonary dysplasia who were supported by mechanical ventilation. Doses of $1 \mathrm{mg} / \mathrm{kg}$ furosemide significantly improved lung compliance (51\% at $2 \mathrm{~h}$ after nebulisation), pulmonary resistance $(28 \%$ at $1 \mathrm{~h})$, and tidal volume (43\% at $1 \mathrm{~h})$, starting as early as $30 \mathrm{~min}$ after the dose. The effect lasted for at least $4 \mathrm{~h}$ in many of the infants and was not associated with diuretic or renal side-effects.

Belik et al. [107] prospectively evaluated the effect of early furosemide-induced diuresis in 39 neonates less than $24 \mathrm{~h}$ of age with clinical respiratory syndrome who received either 4 doses of furosemide $(1 \mathrm{mg} / \mathrm{kg})$ or no diuretic. The furosemide group overall showed a significant decrease $(p<0.01)$ in alveolar-arterial oxygen gradient, and peak inspiratory pressure ( $32 \mathrm{~h}$ versus $52 \mathrm{~h})$ accentuated in the subgroup with 1,000 to $1,500 \mathrm{~g}$ birthweight, while no increase in urine output was observed for the infants weighing $<1,000 \mathrm{~g}$. A significant reduction in supplemental oxygen and need for ventilatory support at $96 \mathrm{~h}$ of age was observed in the furosemide-treated, less than 1,500 $\mathrm{g}$ infants. The results by Blik et al. [107] suggest that early furosemide-induced diuresis, particularly in infants weighing 1,000 to $1,500 \mathrm{~g}$ at birth, promotes improvement in pulmonary functions in respiratory distress syndrome and leads to faster reduction in oxygen and ventilator support.

The literature on the effects of inhaled furosemide on pulmonary mechanics is discordant. Some authors found that inhaled furosemide improves lung compliance whereas other authors found that inhaled furosemide has no significant improvement on lung mechanics. It is difficult to draw a conclusion about the efficacy of inhaled furosemide on lung function. Stewart et al. [11] reviewed the risk and benefits of inhaled furosemide administration in preterm infants with respiratory distress syndrome. These authors conclude that there are no data to support routine administration of furosemide in preterm infants with respiratory distress syndrome. Brion and Soll [13] assessed the risks and benefits of diuretic administration in preterm infants with respiratory distress syndrome and reached the same conclusions achieved by Stewart et al. [11].

\subsection{Furosemide in Preterm Infants with a Patent Ductus Arteriosus}

Furosemide stimulates the renal synthesis of prostaglandin E2 [12], a potent dilator of the ductus arteriosus. Thus, furosemide has an opposite effect to ibuprofen and indomethacin which are the drugs used to close the patent ductus arteriosus. Recently, Stewart et al. [11] and Brion and Soll [13] reached 
the conclusion that elective administration of furosemide to any infants with respiratory distress syndrome should be carefully weighed against the risk of precipitation of a symptomatic patent ductus arteriosus.

Lee et al. [108] identified the effects of furosemide, after indomethacin administration on the rate of patent ductus arteriosus closure and renal function, in preterm infants with a gestational age $<34$ weeks and a birthweight $<2,000 \mathrm{~g}$ receiving indomethacin therapy (one course: $0.2-0.1-0.1 \mathrm{mg} / \mathrm{kg}$ every $12 \mathrm{~h}$ ) mostly started $<48 \mathrm{~h}$ after birth. Thirty-five infants received furosemide $(1 \mathrm{mg} / \mathrm{kg})$ and 33 infants were the controls. Each infant received indomethacin. The outcomes were the closure of patent ductus arteriosus and the presence of acute renal failure. These authors found that there were no differences in the patent ductus arteriosus closure rate between furosemide $(85 \%)$ and the controls $(93 \% ; p=0.437)$. The incidence of acute renal failure (serum creatinine $>1.6 \mathrm{mg} / \mathrm{dL}$ ) was greater in the furosemide group $(59 \%)$ than in the control group $(10 \% ; p<0.001)$. Lee et al [108] conclude that the use of furosemide in combination with indomethacin increased the incidence of acute renal failure but did not affect the patent ductus closure rate in preterm infants.

Brion and Campbell [109] assessed studies for possible bias and for quality of assessment of ductal patency. These authors studied whether furosemide affects the incidence of failure of patent ductal closure after indomethacin treatment. Furosemide administration did not significantly increase the risk of failure of ductal closure; however, sample size was insufficient to rule out even a $31 \%$ increase. There is not enough evidence to support the administration of furosemide to premature infants treated with indomethacin for symptomatic patent ductus arteriosus.

Green et al. [110] administered furosemide $(1 \mathrm{mg} / \mathrm{kg})$ to 33 premature infants with the respiratory distress syndrome, to determine whether it increased the incidence of patent ductus arteriosus. Furosemide stimulates the synthesis of prostaglandin E2 which inhibits the closure of the ductus arteriosus. Chlorothiazide, a diuretic that does not stimulate prostaglandin E2 synthesis, was used as the control drug in other 33 preterm infants. The incidence of patent ductus arteriosus was significantly higher $(p<0.02)$ in the furosemide group (18 out of 33 infants; 54\%) than in the chlorothiazide group ( 8 out of 33; 24\%). Six infants, all from the furosemide group, who did not show evidence of a patent ductus during the study were later found to have one. When the analysis was repeated after the fifth day of life, prostaglandin E2 excretion tripled after furosemide administration, whereas no increase occurred with chlorothiazide. Green et al. [110] conclude that furosemide increases the incidence of patent ductus arteriosus in premature infants with the respiratory distress syndrome, probably through a prostaglandin-mediated process.

Sulyok et al. [12] studied the effects of furosemide (1 mg/kg intramuscularly) on prostaglandin E2 and prostaglandin F2 $\alpha$ synthesis in 19 newborn infants with a mean gestational age 38.7 weeks (range 36 to 41 weeks) and with a mean birthweight of 3,009 g (range 2,700 to 4,150 g) at the postnatal age of 4 to 7 days. After the administration of furosemide, urinary prostaglandin E2 increased from $17.53 \pm$ 3.37 to $23.73 \pm 3.16 \mathrm{ng} / 12 \mathrm{~h}(p<0.025)$ and prostaglandin F $\alpha$ increased from $16.48 \pm 4.12$ to $26.27 \pm$ $4.12 \mathrm{ng} / 12 \mathrm{~h}(p<0.05)$. These authors concluded that $1 \mathrm{mg} / \mathrm{kg}$ furosemide increases the urinary excretion of prostaglandin E2 and prostaglandin F2 $\alpha$ in newborn infants.

Friedman et al. [111] measured the urinary excretion of prostaglandin E2 in 7 sick low-birthweight infants. After $1 \mathrm{mg} / \mathrm{kg}$ furosemide, prostaglandin E2 excretion rate increased from $0.4 \pm 0.04$ to $1.3 \pm$ $0.2 \mathrm{ng} / \mathrm{mg}$ creatinine. Following the administration of indomethacin to 2 patients with patent ductus arteriosus, the urinary excretion of prostaglandin E2 decreased. These results demonstrate that 
furosemide enhances urinary excretion of prostaglandin E2 by mechanisms which may reflect an increase in prostaglandin synthesis. Indomethacin, which is a prostaglandin synthetase inhibitor, decreases the urinary excretion of prostaglandin E2.

Yeh et al. [112] investigated if furosemide would prevent the renal side-effects of indomethacin therapy in premature infants with patent ductus arteriosus. Nine premature infants received indomethacin alone, and ten premature infants received indomethacin followed immediately by furosemide. Infants who received indomethacin and furosemide had significantly higher urine output $(p<0.05)$ and higher GFR $(p<0.05)$ than those of infants who received indomethacin alone. Seven infants in each group responded to indomethacin therapy with the disappearance of patent ductus arteriosus murmur which prevented the renal side-effects of indomethacin therapy and yet did not affect the efficacy of indomethacin in the closure of the patent ductus arteriosus.

\subsection{Ototoxicity Following Furosemide Administration to Adults and Neonates}

Little is known about the ototoxicity due to furosemide administration to neonates and most of the information deals with adult patients. Schwartz et al. [113] reported transitory hearing loss in five adult patients who received high doses of furosemide intravenously. Heidland and Wigand [14] found that among patients with severe renal failure, infusion of furosemide at a constant rate of $25 \mathrm{mg} / \mathrm{min}$ caused noticeable hearing loss in two thirds of their patients. When the infusion rate was reduced to $15 \mathrm{mg} / \mathrm{min}$, only minor hearing losses were reported. These authors concluded that furosemide should be given at a rate less than $4 \mathrm{mg} / \mathrm{min}$ to adult patients to avoid hearing loss. Morelli et al. [114] studied the effects of furosemide in ten adult patients with chronic renal failure. The patients were given 2,000 $\mathrm{mg}$ of furosemide in $200 \mathrm{~mL}$ of isotonic saline over $30 \mathrm{~min}$ period. This resulted in tinnitus and deafness which lasted about $90 \mathrm{~min}$ in all patients who recovered normal hearing later. Fries et al. [115] found no hearing loss among adult patients with renal failure who received 500 or 1,000 $\mathrm{mg}$ of furosemide by infusion over six hours. Rastogi et al. [116] reported no episodes of hearing loss in patients receiving oral doses of furosemide up to $2 \mathrm{~g}$ daily. Some authors [117-119] have reported permanent hearing loss following smaller oral doses of furosemide. Wigand and Heidland [120] reported audiometric studies in patients receiving furosemide. They found that rapid infusion of high doses of furosemide ( $1 \mathrm{~g}$ in $40 \mathrm{~min}$ ) produced acute hearing loss in half of the patients studied. These reversible hearing losses were greatest in the middle frequency range. Although most cases of furosemide ototoxicity have been reversible, some authors [117-119,121,122] have reported permanent deafness after furosemide administration. Kshirsagar et al. [123] reported a case of hearing loss following $25 \mathrm{mg} / \mathrm{kg}$ of furosemide infused slowly intravenously over $4 \mathrm{~h}$ in a patient with nephritic syndrome.

Among 547 preterm infants of $\leq 34$ weeks of gestation, eight infants $(1.46 \%)$ developed severe progressive and bilateral sensorineural hearing loss [124]. Perinatal risk factors of infants with hearing loss were comparable with those of a control group matched for gestational age, birthweight and perinatal complications. There was an association of hearing loss with higher incidence of perinatal complications. Ototoxicity appeared closely related to a prolonged administration and higher total dose of ototoxic drugs, particularly aminoglycosides and furosemide. Borradori et al. [124] strongly recommend prospectively and regularly performing audiologic assessment in sick preterm infants as hearing loss is of delayed onset and in most cases bilateral and severe. 
The Neonatal Formulary [10] states that concurrent furosemide use significantly increases the risk of aminoglycosides ototoxicity. Aminoglycosides should not be administered in association with furosemide. Methods of avoiding ototoxicity include slow continuous infusion rather than bolus injection, use of divided oral dose regimens, and the measurement of blood levels to avoid exceeding $50 \mu \mathrm{g} / \mathrm{mL}$ of furosemide [125]. If a diuretic response cannot be obtained using the above measures, the substitution of another diuretic such as bumetanide is suggested to maintain the therapeutic response and minimize the ototoxicity [125].

Rybak et al. [126] investigated the effects of furosemide on cochlear function and the stria vascularis ultrastructure in rats of various postnatal ages. After an intravenous injection of furosemide $(35 \mathrm{mg} / \mathrm{kg}$ ) to anesthetized rats, the endocochlear potential and compound action potential of the eighth nerve were recorded. Rat pups 9 to 28 days of age had much greater reduction of endocochlear potential and elevation of the compound action potential threshold than animals older than 30 days. These findings support the concept of a critical period of susceptibility to ototoxic drugs during development and could have important clinical implications in premature infants.

\subsection{Furosemide and the Risk for Nephrocalcinosis in Preterm Infants}

Infants with low birthweight treated with chronic furosemide therapy are at risk for the development of intra-renal calcifications [16]. The pathogenesis of nephrocalcinosis in very low birthweight infants appears to be multifactorial. The vulnerability of extreme immaturity and the underdevelopment of renal function may be the most important variables. Hypercalciuria is common in very low birthweight infants, yet not all develop nephrocalcinosis. Decreased GFR, low citrate excretion, and frequently an alkaline urine are in part due to the immaturity of renal function of these infants. The bronchopulmonary dysplasia, frequently requiring furosemide that may cause phosphaturia and magnesium depletion, and that may increase calcium excretion, are more common in the smallest and sickest of premature infants [16].

Giapros et al. [127] estimated renal glomerular and tubular functions and kidney length during the 2 years of life of preterm infants with nephrocalcinosis associate with prematurity. The study cohort comprised 63 infants with nephrocalcinosis and 44 control subjects who were matched for gender, gestational age and birthweight. These authors concluded that nephrocalcinosis in the preterm infants was associated with impaired renal tubular function and a shorter kidney length in the first year of life.

Nasseri et al. [128] determined the incidence and risk factors of nephrocalcinosis in 49 infants with a birthweight of about $1,500 \mathrm{~g}$ treated with furosemide. Nephrocalcinosis was observed in 13 (26.5\%) infants and was bilateral in $7(14.3 \%)$ infants. The mean age of diagnosis of nephrocalcinosis was 52.6 days (range 30-123 days). The mean duration of ventilation was significantly less in infants with than without nephrocalcinosis $(p=0.02)$, and the mean levels of urine calcium and phosphate, at 4 weeks of age, were respectively $(p=0.013 ; p=0.048)$. Using logistic regression analysis, family history of renal stone $(p=0.002)$ and urine calcium/creatinine ratio were significant $(p=0.011)$ predictors of nephrocalcinosis. Nasseri et al. [128] conclude that family history of renal stone and urine calcium/creatinine ratio are the major risk factors of nephrocalcinosis in very low birthweight neonates.

Gimpel et al. [129] determined which of the many risks factors for nephrocalcinosis in preterm infants are most relevant. Fifty-five infants with a gestational age $<32$ weeks and a body median 
weight $1,010 \mathrm{~g}$ (range 500-2,070 g) were studied. In multivariate analysis, the strongest independent risk factor was furosemide therapy above $10 \mathrm{mg} / \mathrm{kg}$ cumulative dose, with 48 -fold increase of nephrocalcinosis. The risk of nephrocalcinosis was 1.65 -fold higher per $100 \mathrm{~g}$ lower weight (1.07 to $2.56 ; p=0.02$ ) and 4.5 -fold higher per $\mathrm{mmol} / \mathrm{l}$ of urinary calcium concentration (1.14 to 17.7 ; $p=0.03$ ). These authors suggest that in preterm infants, furosemide should be prescribed with caution and close monitoring of calcium excretion is advisable.

Ketkeaw et al. [130] analysed 36 infants with a gestational age and a body weight less than 32 weeks and 1,250 g, respectively. Fourteen infants had abnormal ultrasound scans compatible with nephrocalcinosis giving an overall incidence of 38.9\%. Factors associated with nephrocalcinosis included severity of respiratory illness, patent ductus arteriosus, oxygen dependency and furosemide therapy. Ketkeaw et al. [130] conclude that very low birthweight and preterm infants have a risk of developing nephrocalcinosis especially those with severe respiratory illness and prolonged use of furosemide.

Pope et al. [131] investigated the history of nephrocalcinosis in premature infants treated with furosemide. Thirteen preterm infants were studied. During hospitalisation and while receiving furosemide, nephrocalcinosis developed in each patient. Patients were divided into two groups based on resolution (six infants) and non resolution (seven infants) according to spontaneous resolution of nephrocalcinosis at any point during follow-up. Mean follow-up after discontinuation of furosemide in the resolution versus non-resolution groups was 10.3 and 7.7 months, respectively. Early data indicate that nephrocalcinosis resolves in approximately $50 \%$ of premature infants 5 to 6 months after discontinuation of furosemide.

Nephrocalcinosis and nephrolithiasis developed in five children after furosemide therapy for congestive heart failure. Elimination of furosemide in three children resulted in resolution of the calcifications. The phenomenon of renal calcification associated with furosemide treatments is more frequent than previously recognized [132].

Downing et al. [133] determined the long-term renal sequelae following the use of furosemide in preterm infants. The renal function of twenty-seven preterm infants with a birthweight $<1500 \mathrm{~g}$ was evaluated at 1 to 2 years of age. Patients were classified into three groups on the basis of status at the time of discharge from the hospital. Group $1(n=7)$ had no furosemide treatment or renal calcifications, group $2(\mathrm{n}=10)$ had furosemide therapy but no calcification, and group $3(\mathrm{n}=10)$ had furosemide therapy with renal calcification. No difference in renal function was observed between groups 1 and 2. Children in group 3 had significantly higher urinary calcium/creatinine ratios and fractional excretion of sodium and lower tubular reabsorption of phosphate than children in the other two groups. Downing et al. [133] conclude that furosemide-related renal calcifications in very low birthweight infants may lead to glomerular and tubular dysfunction; further long-term follow-up of this population is recommended.

Downing et al. [134] performed a prospective longitudinal renal ultrasound investigation on 117 premature infants. Of these infants, 20 had intra-renal calcifications. Eight patients at age $16.3 \pm 2.6$ months had sonographic resolution of renal calcifications, $6.6 \pm 1.1$ months after furosemide therapy had been discontinued. Twelve children, continued to receive furosemide for their chronic lung disease demonstrating significant association between chronic use of furosemide and persistence to the renal 
calcification $(p<0.001)$. These authors conclude that discontinuation of furosemide therapy is associated with resolution of the renal calcifications.

Jequier and Kaplan [135] reported a retrospective study of 68 infants with increased medullary echogenicity on renal ultrasound examination showed nephrocalcinosis to be present in 42 patients. The cause was believed to be iatrogenic in 30 and non-iatrogenic in 12 infants. Furosemide therapy was responsible for 11 of the cases of iatrogenic nephrocalcinosis.

Kenney et al. [136] treated three very low birthweight infants with furosemide for bronchopulmonary dysplasia. All infants developed medullary nephrocalcinosis identifiable by real time ultrasound. The sonographic findings of diffuse medullary hyper-echogenicity appeared to be specific for nephrocalcinosis.

Hufnagle et al. [137] observed that ten premature infants developed renal calcification while receiving long-term furosemide therapy. These infants received $2 \mathrm{mg} / \mathrm{kg} /$ day of furosemide for at least 12 days before calcifications were noted on abdominal roentgenograms. Calcifications included small flecks, isolated stones, staghorn calculi and nephrocalcinosis. Analysis of stone showed calcium oxalate and calcium phosphate. Infants who were not receiving furosemide had no calcifications. The infants with renal calcifications had rates of calcium excretion 10 to 20 times the normal. These authors conclude that furosemide, in doses of at least $2 \mathrm{mg} / \mathrm{kg} /$ day for at least 12 days can be associated with renal calcifications. The probable mechanism of the stone formation is hypercalciuria, primarily caused by furosemide.

\subsection{Furosemide may Yield Hypercalcemia in Neonates}

Chang et al. [138] searched the factors significantly associated with renal calcifications in 102 infants with very low birthweight. Only 6 infants $(6 \%)$ had renal calcification at term or before discharge compared with 96 who did not. Factors associated with renal calcification included furosemide therapy ( $33 \%$ versus $3 \% ; p=0.027$ ), and dexamethasone therapy ( $50 \%$ versus $2 \%$; $p=0.001)$. Three of six patients had spontaneous remission of renal calcification. Chang et al. [138] concluded that the incidence of renal calcification in very low birthweight infants was relatively low, and the calcification was transient in one-half of the infants. Extremely premature, sick infants requiring long-term ventilation, and those receiving furosemide or dexamethasone were more likely to have calcification.

Srivastava et al. [139] reported two infants with parathyroid hormone-related protein hypercalcemia secondary to congenital mesoblastic. Pre-operative hypercalcemia was corrected with saline hydration, furosemide, calcitonin and/or pamidronate.

Nair et al. [140] reported a 30-day-old infant with subcutaneous fat necrosis and symptomatic hypercalcemia, who developed metastatic calcification in the subcutaneous tissue, kidneys, pericardium and brain. The infant had anemia, hypertriglyceridemia and hypercholesterolemia. The infant was managed with intravenous saline, furosemide, oral steroids and bisphosphonates and improved with treatment.

Pradhan and Leonard [141] reported a 5-day-old infant with severe associated hypercalcemia secondary to a solid tumor in the pelvis. Aggressive pharmacological treatment with furosemide, pamidronate, and calcitonin failed to reduce the serum calcium adequately. Implementation of calcium-free hemodialysis resulted in a rapid reduction of serum calcium from 22.6 to $11.6 \mathrm{mg} / \mathrm{dL}$. 


\subsection{Furosemide, Acetazolamide and Hydrocephalus}

Hydrocephalus is an excess accumulation of cerebrospinal fluid in or around the brain. Although the standard treatment of hydrocephalus is cerebrospinal fluid shunting, there are certain circumstances in which medical treatment, alone or in combination with shunting, has been suggested as an alternative. The incidence of development delay, cerebral palsy, epilepsy and visual impairment in surviving children is variable. The most common treatment of posthemorragic hydrocephalus involves permanent ventricular shunting. Conservative treatment with acetazolamide and furosemide does not seem to confer any advantage to the management of posthemorragic hydrocephalus [142].

Whitelaw et al. [143] reported a different experience. These authors stated that acetazolamide and furosemide, which both reduce the production of cerebrospinal fluid, have been suggested as noninvasive therapies to reduce hydrocephalus and the need for ventriculo-peritoneal shunting.

Libenson et al. [144] evaluated the efficacy of acetazolamide and furosemide in avoiding shunting procedures in preterm infants with posthemorragic hydrocephalus and increased intracranial pressure. Posthemorragic infants were randomized to acetazolamide and furosemide treatment or serial lumbar puncture and monitored until not receiving medications or having undergone shunting. Ten infants with posthemorragic hydrocephalus were randomized to acetazolamide and furosemide treatment and 6 to serial lumbar puncture. Acetazolamide and furosemide therapy is useful in the treatment of preterm infants with posthemorragic hydrocephalus. Because a significant number of infants treated with both acetazolamide and furosemide developed nephrocalcinosis, close monitoring for increased calcium excretion in the urine, or use of acetazolamide without furosemide, is advised.

Eleven premature infants with posthemorragic hydrocephalus were monitored for the development of hypercalciuria during treatment using urine calcium/creatinine ratios [145]. Seven of 11 infants (64\%) developed hypercalciuria; five of those seven infants had nephrocalcinosis. Infants who developed nephrocalcinosis had urine calcium/creatinine ratios ranging from 0.5 to 4.0. In all five infants with nephrocalcinosis, renal calculi decreased and urine calcium/creatinine ratios improved after drug therapy was discontinued. The combined use of acetazolamide and furosemide as therapy for posthemorragic hydrocephalus places premature infants at high risk for nephrocalcinosis.

Medical treatment with $100 \mathrm{mg} / \mathrm{kg} / \mathrm{day}$ acetazolamide and furosemide $1 \mathrm{mg} / \mathrm{kg} / \mathrm{day}$ can be an effective alternative to shunting by halting progression of hydrocephalus until such time as sutures can become fibrosed and spontaneous arrest can occur [146]. In an approximately selected population older than 2 weeks with hydrocephalus of various origin, the success rate in avoiding shunting is greater than $50 \%$. The dramatic difference between the number of hospitalizations of patients with shunts and those treated medically, and the potential of avoiding shunt dependence would appear to make an initial trial with medical therapy worthwhile.

\subsection{Side-Effects of Furosemide in Neonates}

Water and electrolyte imbalances occur frequently, especially hyponatremia, hypokalemia, and hypochloremic alkalosis after furosemide administration [7]. Hypercalciuria and development of renal calculi occur with long-term furosemide therapy [7]. Furosemide is potentially ototoxic, especially in patients also receiving aminoglycosides [7]. It is important to avoid other ototoxic drugs such as the 
aminoglycosides in order not to potentiate furosemide ototoxicity [10]. The risk of ototoxicity is dependent on high serum furosemide concentrations, continuous infusion may be used to reduce its incidence [30,147]. In the very preterm infants, $\mathrm{t}_{1 / 2}$ may be as long as $24 \mathrm{~h}$, making progressive drug accumulation possible with repeated use, and this may be a factor in the increased risk of serious lateonset deafness seen in children exposed to sustained treatment in the neonatal period [10]. Premature neonates $<32$ weeks postmenstrual age have an increased risk of developing high serum furosemide concentrations due to prolonged $t_{1 / 2}$ and, therefore, dosing schedules should be adjusted for this age group [148]. Furosemide stimulates renal synthesis of prostaglandin E2 [12], thus enhancing, and modifying, renal blood flow. Early use is associated with some increase in the incidence of symptomatic patent ductus arteriosus in infants requiring ventilation for respiratory distress, and this might be due to increased prostaglandin production [10]. Thus, furosemide has an opposite effect to ibuprofen and indomethacin which are the drugs used to close the patent ductus arteriosus. Elective administration of furosemide to any patient with respiratory distress syndrome should be carefully weighed against the risk of precipitation of a symptomatic patent ductus arteriosus. The use of furosemide in infants may lead to nephrocalcinosis and nephrolithiasis, due to high urinary calcium excretion [149].

\section{Discussion}

Furosemide is a loop diuretic because it inhibits activity of the $\mathrm{Na}^{+}-\mathrm{K}^{+}-2 \mathrm{Cl}^{-}$symporter in the thick ascending limb of the loop of Henle. Other loop diuretics are bumetanide, ethacrynic acid, torsemide, axosemide, piretanide and tripamide [3]. Furosemide is the most used loop diuretic in the neonatal intensive care unit $[1,2]$. Although the proximal tubule reabsorbs about $65 \%$ of filtered $\mathrm{Na}^{+}$, diuretics acting only in the proximal tubule have limited capacity because the thick ascending limb has a great reabsorptive capacity and reabsorbs most of the rejectate from proximal tubule. Diuretics acting predominantly at sites past the thick ascending limb also have limited efficacy because only a small percentage of the filtered $\mathrm{Na}^{+}$load reaches these more distal sites. In contrast, inhibitors of $\mathrm{Na}^{+}-\mathrm{K}^{+}-$ $2 \mathrm{Cl}^{-}$symport in the thick ascending limb are highly efficacious and for this reason are called highceiling diuretics. The efficacy of inhibitors of $\mathrm{Na}^{+}-\mathrm{K}^{+}-2 \mathrm{Cl}^{-}$symport in the thick ascending limb of the loop of Henle is due to approximately $25 \%$ of the filtered $\mathrm{Na}^{+}$load normally being reabsorbed by the thick ascending limb, and nephron segments past the thick ascending limb do not possess the reabsorptive capacity to rescue the flood of rejectate exiting the thick ascending limb [3].

The extracellular water is 2.4-fold higher in neonates than in adult subjects [17]. In adults, furosemide $\mathrm{Vd}$ is $0.13 \mathrm{l} / \mathrm{kg}$ [5], suggesting that furosemide is mainly distributed into the extracellular water and in neonates $\mathrm{Vd}$ is larger than in adults. In fullterms, $\mathrm{Vd}$ of furosemide is larger than in preterms $[63,64]$ suggesting that the fraction of the administered dose of furosemide distributed in periphery is higher in fullterm infants.

In adults, $t_{1 / 2}$ is $1.3 \mathrm{~h}$ [5] and this figure is much less than $t_{1 / 2}$ of neonates which ranges from 7.7 [61,64] to $26.8 \mathrm{~h}$ [63]. Thus, furosemide is eliminated more slowly in neonates than in adults and, consequently, furosemide $\mathrm{Cl}$ is lower in neonates. This is a factor that makes progressive drug accumulation possible with repeated use. With the increasing of the postmenstrual age, the elimination of furosemide increases and the tendency of accumulating drug in plasma decreases [6]. The reason for the prolonged 
half-life of furosemide in newborn infants is the slow renal elimination, related to immature renal function, which is compounded by a reduced metabolic elimination. The kidney maturation drives the furosemide pharmacokinetics.

Drug elimination involves both renal elimination and metabolism. Aranda et al. [61] found that furosemide is metabolised into an acidic metabolite and is conjugated with glucuronic acid. In contrast, Tuck et al. [62] found that furosemide is not metabolised in neonates. The mid-gestation human fetal liver [56] and kidney [57] have significant levels of glucuronosyl transferase activity and its endogenous substrate adenosine 5'-diphosphoglucuronic acid [150].

In adults, renal elimination of furosemide occurs by glomerular filtration as well as by tubular secretion via a general organic anionic secretory pathway located in the proximal convolute tubule [151-154]. In neonates, furosemide elimination is decreased because of a low rate of tubular secretion, and in infants with very low body weight, filtration is the major route of renal elimination [6].

It has been suggested giving furosemide by continuous intravenous infusion to pediatric patients following cardiac surgery $[82,84,85,88,92]$. Appropriate maintenance of patient's volume status is an important part of the perioperative management of patients undergoing cardiac surgery [79-81]. Trials assessing efficacy and safety of continuous versus intermittent intravenous infusion of furosemide in pediatric patients after cardiopulmonary bypass surgery revealed that the total furosemide dose administered by continuous intravenous infusion was generally less than the dose by intermittent intravenous administration $[82,84,88,92]$. The initial rate of the continuous furosemide intravenous infusion is $0.1 \mathrm{mg} / \mathrm{kg} / \mathrm{h}$ and is preceded by a loading bolus injection of $1 \mathrm{mg} / \mathrm{kg}$ in patients with normal renal function and $2 \mathrm{mg} / \mathrm{kg}$ in patients with acute renal failure [94].

In the continuous intravenous infusion there is less variability in urine output as well as less losses of sodium and chloride than in the intermittent intravenous infusion of furosemide [82]. The efficacy of furosemide in terms of urinary output is satisfactory in both continuous and intermittent intravenous infusion. However, continuous intravenous infusion of furosemide gives a urinary output per dose of drug significantly larger than after intermittent intravenous infusion with lesser fluctuations and fluid replacement than intermittent infusion [84]. Furosemide administered by continuous infusion is advantageous in the post-operative pediatric patient because of a more predictable urine output with less drug requirement and less urinary loss in sodium and chloride.

When the urine output is $<1 \mathrm{~mL} / \mathrm{kg} / \mathrm{h}$, the dose of furosemide can be increased to $0.4 \mathrm{mg} / \mathrm{kg} / \mathrm{h}$ $[82,84,88,149]$. The starting dose for continuous intravenous furosemide infusion ranges from 0.08 to $0.1 \mathrm{mg} / \mathrm{kg} / \mathrm{h}$ and could be adjusted every $24 \mathrm{~h}$ in steps of $0.1 \mathrm{mg} / \mathrm{kg} / \mathrm{h}$.

Tolerance to furosemide can be induced through different but complementary homeostatic mechanisms in the kidney $[95,96]$. The mechanism which underlies the development of tolerance is dehydration. Segar et al. [155] stated that tolerance to furosemide appears to be explained by compensatory increased sodium and chloride reabsorption without changes in creatinine clearance. The administration of furosemide enhances diuresis, natriuresis, and chloruresis and overlap the rapid development of tolerance to furosemide in infants with bronchopulmonary dysplasia by blocking the compensatory increase in renal sodium and chloride absorption. The tolerance can be overcome by combination diuretic therapy such as a loop diuretic and a thiazide.

The dosing schedule of continuous intravenous infusion of furosemide in neonates treated with ECMO is largely empirical because of the variable renal function and the altered furosemide 
pharmacokinetics. van der Vorst et al. [9] observed that the dose of the continuous intravenous infusion of furosemide ranged from 0.02 to $0.17 \mathrm{mg} / \mathrm{kg} / \mathrm{h}$, and $39 \%$ of the patients needed additional diuretic. The evaluated furosemide regimen of $0.2 \mathrm{mg} / \mathrm{kg} / \mathrm{h}$ preceded by a loading dose of $1 \mathrm{mg} / \mathrm{kg}$ is an effective means to obtain rapid and sufficient diuresis without cardiovascular instability in neonates treated with ECMO with a relatively low interindividual variability in urine production.

Some authors found a benefit of inhaled furosemide in preterm infants with respiratory distress syndrome. Other authors found a lack of effect of inhaled furosemide on lung mechanics. Steward et al. [11] and Brion and Soll [13] reviewed the risk and benefits of inhaled furosemide in preterm infants with respiratory distress syndrome. These authors concluded that there are no data to support routine administration of furosemide in preterm infants with respiratory distress syndrome. One $\mathrm{mg} / \mathrm{kg}$ inhaled furosemide does not improve the pulmonary mechanics in ventilated-dependent infants with severe bronchopulmonary dysplasia [102]. Inhaled furosemide has no significant clinical effects in hospitalised infants with viral-bronchitis [103].

Prabhu et al. [104] reported different results, these authors stated that a single dose of $1 \mathrm{mg} / \mathrm{kg}$ of nebulised furosemide improves pulmonary function in premature infants with evolving chronic lung disease without adverse effects on fluid and electrolyte balance. After aerosolized furosemide $(2 \mathrm{mg} / \mathrm{kg}$ ), static respiratory compliance increased significantly by $24.3 \%$ and $23.2 \%$ as percentage change from the baseline value at 1 and $2 \mathrm{~h}(p=0.014$ and 0.02 , respectively). Also tidal volume increased significantly by $33.8 \%$ and $28.7 \%$ at 1 and $2 \mathrm{~h}$, respectively ( $p=0.004$ and $0.009 ;[105])$.

Furosemide stimulates renal synthesis of prostaglandin E2 [12], a potent dilator of the ductus arteriosus. After $1 \mathrm{mg} / \mathrm{kg}$ furosemide intramuscularly, urinary prostaglandin E2 increased from $17.53 \pm 3.37$ to $23.73 \pm 3.16 \mathrm{ng} / 12 \mathrm{~h}(p<0.025)$. Thus, furosemide has an opposite effect to ibuprofen and indomethacin which are the drugs used to close the patent ductus arteriosus.

Brion and Campbell [109] studied whether furosemide affects the incidence of failure of patent ductal closure after indomethacin administration. These authors observed that there is not enough evidence to support the administration of furosemide to preterm infants treated with indomethacin for symptomatic patent ductus arteriosus. After $1 \mathrm{mg} / \mathrm{kg}$ furosemide, prostaglandin $\mathrm{E} 2$ excretion rate increased from $0.4 \pm 0.04$ to $1.3 \pm 0.2 \mathrm{ng} / \mathrm{mg}$ creatinine. Following the administration of indomethacin to 2 patients with patent ductus arteriosus, the urinary excretion of prostaglandin E2 decreased [111]. These results demonstrate that furosemide enhances urinary excretion of prostaglandin E2 by mechanisms which may reflect an increase in prostaglandin synthesis.

Lee et al. [108] administered furosemide $(1 \mathrm{mg} / \mathrm{kg})$ to preterm infants with gestational age $<34$ weeks. Each infant received indomethacin. Furosemide, in combination with indomethacin, increased the incidence of acute renal failure but did not affect the patent ductus closure rate in preterm infants.

Infants who received indomethacin and furosemide had significantly higher urine output $(p<0.05)$ and higher GFR $(p<0.05)$ than those of infants who received indomethacin alone [112]. Furosemide prevented the renal side effects of indomethacin therapy and yet did not affect the efficacy of indomethacin in the closure of the patent ductus arteriosus.

Furosemide may cause ototoxicity in neonates, which may be permanent in some cases. Heidland and Wigand [14] suggested that furosemide should be given at a rate less than $4 \mathrm{mg} / \mathrm{min}$ to adult patients to avoid hearing loss. Ototoxicity appears closely related to a prolonged administration and higher total dose of ototoxic drugs, particularly aminoglycosides [124]. Aminoglycosides should not 
be administered in association with furosemide [10]. Methods of avoiding ototoxicity include slow continuous infusion rather than bolus injection, use of divided oral dose regimens, and the measurement of blood levels to avoid exceeding $50 \mu \mathrm{g} / \mathrm{mL}$ furosemide in neonates [125]. If a diuretic response cannot be obtained using the above measures, the substitution of another diuretic such as bumetanide is suggested to maintain therapeutic response and minimize the ototoxicity [125].

Preterm infants treated with chronic furosemide may develop intra-renal calcification [134]. The pathogenesis of nephrocalcinosis in very low birthweight infants may depend on the underdevelopment of renal function. Renal injury in early life may lead to hypertension and renal disease in adulthood [127]. Nephrocalcinosis in the preterm infants was associated with impaired renal tubular function and a shorter kidney length in the first year of life [127]. The risk of nephrocalcinosis is 1.65-fold higher per $100 \mathrm{~g}$ lower weight and 4.5-fold higher per mmol/1 of urinary calcium concentration [129].

Nasseri et al. [128] using logistic regression analysis, observed that family history of renal stone and urine calcium/creatinine ratio are the major risk factors of nephrocalcinosis in very low birthweight neonates. Factors associated with nephrocalcinosis include severity of respiratory illness, patent ductus arteriosus, oxygen dependency and furosemide therapy [130]. Furosemide-related renal calcifications in very low birthweight infants may lead to glomerular and tubular dysfunction [133]. Discontinuity of furosemide therapy is associated with resolution of renal calcifications. Furosemide therapy is responsible for cases of iatrogenic nephrocalcinosis [135] and renal calcification has rates of calcium excretion 10 to 20 times the normal [137]. Furosemide or dexamethasone therapy is associated with renal calcification [138] and extremely premature sick infants requiring long-term ventilation are more likely to have calcification. Furosemide administered in association with acetazolamide is neither effective nor safe in treating posthemorragic hydrocephalus.

\section{Conclusions}

Kidney maturation drives furosemide pharmacokinetics. There is a remarkable interindividual variability in the kinetic parameters of furosemide in neonates. Furosemide $t_{1 / 2}$ is longer and $\mathrm{Cl}$ is smaller in preterm than fullterm infants. $\mathrm{t}_{1 / 2}$ of furosemide shortens and $\mathrm{Cl}$ increases with postnatal development. Continuous intravenous infusion of furosemide in pediatric patients undergoing cardiac surgery is preferable to intermittent intravenous infusion. The continuous infusion of furosemide in ECMO is required to warrant urine production. Furosemide may be administered by inhalation; nebulised furosemide may improve pulmonary function in premature infants. However, some authors found no effect of inhaled furosemide on lung mechanics. Furosemide stimulates the synthesis of prostaglandin E2 and the administration of furosemide to preterm infants may yield a patent ductus arteriosus. Infants with low birthweight treated with chronic furosemide are at risk for the development of intra-renal calcification. Implementation of calcium-free hemodialysis resulted in a rapid reduction of serum calcium concentration. Some authors observed that acetazolamide and furosemide confer some advantages to the posthemorragic treatment of the hydrocephalus. Other authors found a lack of effect of these drugs on the posthemorragic hydrocephalus. The effect of acetazolamide and furosemide on the posthemorragic hydrocephalus is still uncertain. 


\section{Acknowledgements}

This work has been supported by the Ministry of the University and Scientific and Technologic Research (Rome, Italy). The author thanks Rosa Baviello, of the Medical Library of the University of Pisa, for the prompt retrieving of the literature. A particular thank to Tessa Piazzini, of the Biomedical Library of the University of Florence, who performed the bibliographic search with EMBASE.

\section{Conflicts of Interest}

The authors declare no conflict of interest.

\section{References}

1. Aranda, J.V.; Collinge, J.M.; Clarkson, S. Epidemiologic aspects of drug utilization in a newborn intensive care unit. Semin. Perinatol. 1982, 6, 148-154.

2. Aranda, J.V.; Clarkson, S.; Collinge, J.M. Changing pattern of drug utilization in a neonatal intensive care unit. Am. J. Perinatol. 1983, 1, 28-30.

3. Reilly, R.F.; Jackson, E.K. Regulation of renal function and vascular volume. In Goodman and Gilman's. The Pharmacological Basis of Therapeutics, 12th ed.; Brunton, L., Chabner, B., Knollman, B., Eds.; Mc Graw Hill: New York, NY, USA, 2011; pp. 682-686.

4. Onrot, J.; Ragno, R.E. Treatment of cardiovascular disorders, hypertension. In Clinical Pharmacology. Basic Principles in Therapeutics, 3rd ed.; Melmon, K.L., Morelli, H.F., Hoffman, B.B., Nierenberg, D.W., Ed.; Mc Graw Hill: New York, NY, USA, 1992; p. 57.

5. Thummel, K.E.; Shen, D.D.; Isoherranen, N. Design and optimization of dosage regimens, pharmacokinetic data. In Goodman \& Gilman's The Pharmacological Basis of Therapeutics, 12th ed.; Brunton, L., Chabner, B., Knollman, B., Eds.; Mc Graw Hill: New York, NY, USA, 2011; p. 1935.

6. Mirochnick, M.H.; Miceli, J.J.; Kramer, P.A.; Chapron, D.J.; Raye, J.R. Furosemide pharmacokinetics in very low birth weight infants. J. Pediatr. 1988, 112, 653-657.

7. Young, T.E.; Mangum, B. Neofax: A Manual of Drugs used in neonatal care. Cardiovascular, 23rd ed.; Thomson Reuters: Montvale, NJ, USA, 2010; pp. 248-249.

8. Schaible, T.; Hermle, D.; Loersch, F.; Demirakca, S.; Reinshagen, K.; Varnholt, V. A 20-year experience on neonatal extracorporeal membrane oxygenation in a referral center. Intensive Care Med. 2010, 36, 1229-1234.

9. Van der Vorst, M.M.; Wildschut, E.; Houmes, R.J.; Gischler, S.J.; Kist-van Holthe, J.E.; Burggraaf, J.; van der Heijden, A.J.; Tibboel, D. Evaluation of furosemide regimens in neonates treated with extracorporeal membrane oxygenation. Crit. Care. 2006, 10, R168.

10. Neonatal Formulary, 6th ed.; John Wiley \& Sons: West Sussex, UK, 2011; pp. 116.

11. Stewart, A.; Brion, L.P.; Soll, R. Diuretics for respiratory distress syndrome in preterm infants. Cochrane Database Syst. Rev. 2011, 12, CD001454.

12. Sulyok, E.; Varga, F.; Németh, M.; Tényi, I.; Csaba, I.F.; Ertl, T.; Györy, E. Furosemide-induced alterations in the electrolyte status, the function of renin-angiotensin-aldosterone system, and the urinary excretion of prostaglandins in newborn infants. Pediatr. Res. 1980, 14, 765-768. 
13. Brion, L.P.; Soll, R.F. Diuretics for respiratory distress syndrome in preterm infants. Cochrane Database Syst Rev. 2008, 1, CD001454.

14. Heidland, A.; Wigand, M.E. The effect of Furosemide at high doses on auditorium sensitivity in patients with uremia. Klin. Wschr. 1970, 48, 1052-1056.

15. Rybak, L.P. Furosemide ototoxicity, clinical and experimental aspects. Laryngoscope 1985, 95, $1-14$.

16. Adams, N.D.; Rowe, J.C. Nephrocalcinosis. Clin. Perinatol. 1992, 19, 179-195.

17. Friis-Hansen, B. Body water compartments in children, changes during growth and related changes in body composition. Pediatrics 1961, 28, 169-181.

18. Heimler, R.; Doumas, B.T.; Jendrzejczak, B.M.; Nemeth, P.B.; Hoffman, R.G.; Nelin, L.D. Relationship between nutrition, weight change, and fluid compartments in preterm infants during the first week of life. J Pediatr. 1993, 122, 110-114.

19. Allegaert, K.; Verbesselt, R.; Naulaers, G.; van den Anker, J.N.; Rayyan, M.; Debeer, A.; de Hoon, J. Developmental pharmacology, neonates are not just small adults. Acta Clin. Belg. 2008, 63, 16-24.

20. Alcorn, J.; McNamara, P.J. Ontogeny of hepatic and renal systemic clearance pathways in infants, part II. Clin. Pharmacokinet. 2002, 41, 1077-1094.

21. Van den Anker, J.N. Pharmacokinetics and renal function in preterm infants. Acta Paediatr. 1996, 85, 1393-1399.

22. Kapur, G.; Mattoo, T.; Aranda, J.V. Pharmacogenomics and renal drug disposition in the newborn. Semin. Perinatol. 2004, 28, 132-140.

23. Allegaert, K.; Anderson, B.J.; van den Anker, J.N.; Vanhaesebrouck, S.; de Zegher, F. Renal drug clearance in preterm neonates, relation to prenatal growth. Ther. Drug Monit. 2007, 29, 284-291.

24. Kearns, G.L.; Abdel-Rahman, S.M.; Alander, S.W.; Blowey, D.L.; Leeder, J.S.; Kauffman, R.E. Developmental pharmacology_-Drug disposition, action, and therapy in infants and children. N. Engl. J. Med. 2003, 349, 1157-1167.

25. Rakhmanina, N.Y.; van den Anker, J.N. Pharmacological research in pediatrics, From neonates to adolescents. Adv. Drug Deliv. Rev. 2006, 58, 4-14.

26. Peters, A.M.; Allison, H.; Ussov, W.Y. Measurement of the ratio of glomerular filtration rate to plasma volume from the technetium-99m diethylene triamine pentaacetic acid renogram, comparison with glomerular filtration rate in relation to extracellular fluid volume. Eur. J. Nucl. Med. 1994, 21, 322-327.

27. Vanpeè, M.; Herin, P.; Zetterstrom, R. Postnatal development of renal function in very low birth weight infants. Acta Pediatr. Scand. 1998, 77, 191-197.

28. Gallini, F.; Maggio, L.; Romagnoli, C.; Marrocco, G.; Tortorolo, G. Progression of renal function in preterm neonates with gestational age $<$ or $=32$ weeks. Pediatr. Nephrol. 2000, 15, 119-124.

29. Awad, H.; el-Safty, I.; el-Barbary, M.; Imam, S. Evaluation of renal glomerular and tubular functional and structural integrity in neonates. Am. J. Med. Sci. 2002, 324, 261-266.

30. Wells, T.G. The pharmacology and therapeutics of diuretics in the pediatric patient. Pediatr. Clin. North Am. 1990, 37, 463-504. 
31. Arant, B.S., Jr. Developmental patterns of renal functional maturation compared in the human neonate. J. Pediatr. 1978, 92, 705-712.

32. Sonntag, J.; Prankel, B.; Waltz, S. Serum creatinine concentration, urinary creatinine excretion and creatinine clearance during the first 9 weeks in preterm infants with a birth weight below 1,500 g. Eur. J. Pediatr. 1996, 155, 815-819.

33. Van der Heijden, A.J.; Grose, W.F.; Ambagtsheer, J.J.; Provoost, A.P.; Wolff, E.D.; Sauer, P.J. Glomerular filtration rate in the preterm infant, the relation to gestational and postnatal age. Eur. J. Pediatr. 1988, 148, 24-28.

34. Van den Anker, J.N.; de Groot, R.; Broerse, H.M.; Sauer, P.J.; van der Heijden, B.J.; Hop, W.C.; Lindemans, J. Assessment of glomerular filtration rate in preterm infants by serum creatinine, comparison with inulin clearance. Pediatrics 1995, 96, 1156-1158.

35. Pachì, A.; Lubrano, R.; Maggi, E.; Giancotti, A.; Giampà, G.; Elli, M.; Mannarino, O.; Castello, M.A. Renal tubular damage in fetuses with intrauterine growth retardation. Fetal Diagn. Ther. 1993, 8, 109-113.

36. Hinchliffe, S.A.; Lynch, M.R.; Sargent, P.H.; Howard, C.V.; van Velzen, D. The effect of intrauterine growth retardation on the development of renal nephrons. Br. J. Obstet. Gynaecol. 1992, 99, 296-301.

37. Robinson, D.; Weiner, C.P.; Nakamura, K.T.; Robillard, J.E. Effect of intrauterine growth retardation on renal function on day one of life. Am. J. Perinatol. 1990, 7, 343-346.

38. Narang, A.; Bhakoo, O.N.; Majumdar, S.; Kumar, C.H. Renal function in SFD and AFD preterm babies. Indian Pediatr. 1993, 30, 201-205.

39. Silver, L.E.; Decamps, P.J.; Korst, L.M.; Platt, L.D.; Castro, L. Intrauterine growth restriction is accompanied by decreased renal volume in the human fetus. Am. J. Obstet. Gynecol. 2003, 188, $1320-1325$.

40. Kushnir, A.; Pinheiro, J.M. Comparison of renal effects of ibuprofen versus indomethacin during treatment of patent ductus arteriosus in contiguous historical cohorts. BMC Clin. Pharmacol. 2011, 11, 8 .

41. Robillard, J.E.; Smith, F.G.; Segar, J.L.; Guillery, E.N.; Jose, P.A. Mechanisms regulating renal sodium excretion during development. Pediatr. Nephrol. 1992, 6, 205-213.

42. Guignard, J.P. Effect of drugs on the immature kidney. Adv. Nephrol. Necker Hosp. 1993, 22, 193-211.

43. Roberts, D.S.; Haycock, G.B.; Dalton, R.N.; Turner, C.; Tomlinson, P.; Stimmler, L.; Scopes, J.W. Prediction of acute renal failure after birth asphyxia. Arch. Dis. Child. 1990, 65, 1021-1028.

44. Vanpée, M.; Blennow, M.; Linné, T.; Herin, P.; Aperia, A. Renal function in very low birth weight infants, normal maturity reached during early childhood. J. Pediatr. 1992, 121, 784-788.

45. Nash, M.A.; Edelmann, C.M., Jr. The developing kidney. Immature function or inappropriate standard. Nephron 1973, 11, 71-90.

46. Bernard, A.M.; Vyskocil, A.A.; Mahieu, P.; Lauwerys, R.R. Assessment of urinary retinolbinding protein as an index of proximal tubular injury. Clin. Chem. 1987, 33, 775-779.

47. Mutti, A. Detection of renal diseases in humans: developing markers and methods. Toxicol. Lett. 1989, 46, 177-191. 
48. Bedir, A.; Ozener, I.C.; Emerk, K. Urinary leucine aminopeptidase is a more sensitive indicator of early renal damage in non-insulin-dependent diabetics than microalbuminuria. Nephron 1996, 74, 110-113.

49. Carr, M.C.; Peters, C.A.; Retik, A.B.; Mandell, J. Urinary levels of the renal tubular enzyme $\mathrm{N}$-acetyl-beta-D-glucosaminidase in unilateral obstructive uropathy. J. Urol. 1994, 151, 442-445.

50. Kilaru, P.; Bakris, G.L. Microalbuminuria and progressive renal disease. J. Hum. Hypertens. 1994, 8, 809-817.

51. Allegaert, K.; van den Anker, J.N.; Naulaers, G.; de Hoon, J. Determinants of drug metabolism in early neonatal life. Curr. Clin. Pharmacol. 2007, 2, 23-29.

52. Hines, R.N.; McCarver, D.G. The ontogeny of human drug-metabolising enzymes: Phase I oxidative enzymes. J. Pharmacol. Exp. Ther. 2002, 300, 355-360.

53. Pacifici, G.M.; Franchi, M.; Colizzi, C.; Giuliani, L.; Rane, A. Sulfotransferase in humans: Development and tissue distribution. Pharmacology 1988, 36, 411-419.

54. Pacifici, G.M.; Franchi, M.; Rane, A. Development of the glucuronyltransferase and sulphotransferase towards 2-naphthol in human fetus. Dev. Pharmacol. Ther. 1990, 14, 108-114.

55. Cappiello, M.; Giuliani, L.; Rane, A.; Pacifici, G.M. Differential development of phenol and catechol sulphotransferases in human fetus. Dev. Pharmacol. Ther. 1991, 16, 83-88.

56. Pacifici, G.M.; Sawe, J.; Kager, L.; Rane, A. Morphine glucuronidation in human fetal and adult liver. Eur. J. Clin. Pharmacol. 1982, 22, 553-558.

57. Pacifici, G.M.; Rane, A. Renal glucuronidation of morphine in human foetus. Acta Pharmacol. Toxicol. 1982, 50, 155-160.

58. Pacifici, G.M.; Santerini, S.; Giuliani, L.; Rane, A. Thiomethyltransferase in humans: development and tissue distribution. Dev. Pharmacol. Ther. 1991, 17, 8-15.

59. Pacifici, G.M.; Romiti, P.; Giuliani, L.; Rane, A. Thiopurinemethyltransferase in humans development and tissue distribution. Dev. Pharmacol. Ther. 1991, 17, 16-23.

60. Pacifici, G.M.; Bencini, C.; Rane, A. Acetyltransferase in humans: Development and tissue distribution. Pharmacology 1986, 32, 283-291.

61. Aranda, J.V.; Lambert, C.; Perez, J.; Turmen, T.; Sitar, D.S. Metabolism and renal elimination of furosemide in the newborn infant. J. Pediatr. 1982, 101, 777-781.

62. Tuck, S.; Morselli, P.; Broquaire, M.; Vert, P. Plasma and urinary kinetics of furosemide in newborn infants. J. Pediatr. 1983, 103, 481-485.

63. Vert, P.; Broquaire, M.; Legagneur, M.; Morselli, P.L. Pharmacokinetics of furosemide in neonates. Eur. J. Clin. Pharmacol. 1982, 22, 39-45.

64. Peterson, R.G.; Simmons, M.A.; Rumack, B.H.; Levine, R.L.; Brooks, J.G. Pharmacology of furosemide in the premature newborn infant. J. Pediatr. 1980, 97, 139-143.

65. Aranda, J.V.; Perez, J.; Sitar, D.S.; Collinage, J.; Portuguez-Malavasi, A.; Duffy, B.; Dupont, C. Pharmacokinetic disposition and protein binding of furosemide in newborn infants. J. Pediatr. 1978, 93, 507-511.

66. Brater, D.C. Determinants of the overall response to furosemide: Pharmacokinetics and pharmacodynamics. Fed. Proc. 1983, 42, 1711-1713. 
67. Mirochnick, M.H.; Miceli, J.J.; Kramer, P.A.; Chapron, D.J.; Raye, J.R. Renal response to furosemide in very low birth weight infants during chronic administration. Dev. Pharmacol. Ther. 1990, 15, 1-7.

68. Pacifici, G.M.; Viani, A.; Taddeucci-Brunelli, G.; Rizzo, G.; Carrai, M.; Schulz, H.U. Effects of development, aging, and renal and hepatic insufficiency as well as hemodialysis on the plasma concentrations of albumin and alpha 1-acid glycoprotein: Implications for binding of drugs. Ther. Drug Monit. 1986, 8, 259-263.

69. Shankaran, S.; Poland, R.L. The displacement of bilirubin from albumin by furosemide. J. Pediatr. 1977, 90, 642-646.

70. Schwartz, P.A.; Rhodes, C.T.; Greene, D.S. Effect of free fatty acid concentration on furosemide binding to human serum albumin. Pharmacology 1981, 22, 364-370.

71. Viani, A.; Rizzo, G.; Carrai, M.; Pacifici, G.M. Interindividual variability in the concentrations of albumin and alpha-1-acid glycoprotein in patients with renal or liver disease, newborns and healthy subjects: implications for binding of drugs. Int. J. Clin. Pharmacol. Ther. Toxicol. 1992, 30, 128-133.

72. Pacifici, G.M.; Viani, A.; Taddeucci-Brunelli, G. Serum protein binding of furosemide in newborn infants and children. Dev. Pharmacol. Ther. 1987, 10, 413-421.

73. Viani, A.; Pacifici, G.M. Bilirubin displaces furosemide from serum protein: the effect is greater in newborn infants than adult subjects. Dev. Pharmacol. Ther. 1989, 14, 90-95.

74. Turmen, T.; Thom, P.; Louridas, A.T.; LeMorvan, P.; Aranda, J.V. Protein binding and bilirubin displacing properties of bumetanide and furosemide. J. Clin. Pharmacol. 1982, 22, 551-556.

75. Viani, A.; Pacifici, G.M. Quantitative contribution of endogenous compounds and hypoalbuminemia in reducing the binding of furosemide in the plasma of newborn infants. Dev. Pharmacol. Ther. 1992, 18, 39-43.

76. Ross, B.S.; Pollak, A.; Oh, W. The pharmacologic effects of furosemide therapy in the low-birthweight infant. J. Pediatr. 1978, 92, 149-152.

77. Woo, W.C.; Dupont, C.; Collinge, J.; Aranda, J.V. Effects of furosemide in the newborn. Clin. Pharmacol. Ther. 1978, 23, 266-271.

78. Prandota, J.; Houin, G. Kinetics of urinary furosemide elimination in infants. Dev. Pharmacol. Ther. 1984, 7, 273-284.

79. Gulbis, B.E.; Spencer, A.P. Efficacy and safety of a furosemide continuous infusion following cardiac surgery. Ann. Pharmacother. 2006, 40, 1797-1803.

80. Bellomo, R.; Raman, J.; Ronco, C. Intensive care unit management of the critically ill patient with fluid overload after open heart surgery. Cardiology 2001, 96, 169-176.

81. Toraman, F.; Evrenkaya, S.; Yuce, M.; Turek, O.; Aksoy, N.; Karabulut, H.; Demirhisar, O.; Alhan, C. Highly positive intraoperative fluid balance during cardiac surgery is associated with adverse outcome. Perfusion 2004, 19, 85-91.

82. Singh, N.C.; Kissoon, N.; al Mofada, S.; Bennett, M.; Bohn, D.J. Comparison of continuous versus intermittent furosemide administration in postoperative pediatric cardiac patients. Crit. Care Med. 1992, 20, 17-21.

83. Wilson, N.J.; Adderley, R.J.; McEniery, J.A. Supraventricular tachycardia associated with continuous furosemide infusion. Can. J. Anaesth. 1991, 38, 502-505. 
84. Luciani, G.B.; Nichani, S.; Chang, A.C.; Wells, W.J.; Newth, C.J.; Starnes, V.A. Continuous versus intermittent furosemide infusion in critically ill infants after open heart operations. Ann. Thorac. Surg. 1997, 64, 1133-1139.

85. Martin, S.J.; Danziger, L.H. Continuous infusion of loop diuretics in the critically ill, a review of the literature. Crit. Care Med. 1994, 22, 1323-1309.

86. Francis, G.S.; Siegel, R.M.; Goldsmith, S.R.; Olivari, M.T.; Levine, T.B.; Cohn, J.N. Acute vasoconstrictor response to intravenous furosemide in patients with chronic congestive heart failure. Activation of the neurohumoral axis. Ann. Intern. Med. 1985, 103, 1-6.

87. Copeland, J.G.; Campbell, D.W.; Plachetka, J.R.; Salomon, N.W.; Larson, D.F. Diuresis with continuous infusion of furosemide after cardiac surgery. Am. J. Surg. 1983, 146, 796-799.

88. Klinge, J.M.; Scharf, J.; Hofbeck, M.; Gerling, S.; Bonakdar, S.; Singer, H. Intermittent administration of furosemide versus continuous infusion in the postoperative management of children following open heart surgery. Intensive Care Med. 1997, 23, 693-697.

89. Van Meyel, J.J.; Smits, P.; Dormans, T.; Gerlag, P.G.; Russel, F.G.; Gribnau, F.W. Continuous infusion of furosemide in the treatment of patients with congestive heart failure and diuretic resistance. J. Intern. Med. 1994, 235, 329-334.

90. Lahav, M.; Regev, A.; Ra'anani, P.; Theodor, E. Intermittent administration of furosemide vs continuous infusion preceded by a loading dose for congestive heart failure. Chest 1992, 102, $725-731$.

91. Vanpeè, M.; Blennow, M.; Linné, T.; Herin, P.; Aperia, A. Renal function in very low birth weight infants: normal maturity reached during early childhood. J. Pediatr. 1992, 121, 784-788.

92. Van der Vorst, M.M.; Ruys-Dudok van Heel, I.; Kist-van Holthe, J.E.; den Hartigh, J.; Schoemaker, R.C.; Cohen, A.F.; Burggraaf, J. Continuous intravenous furosemide in haemodynamically unstable children after cardiac surgery. Intensive Care Med. 2001, 27, 711-715.

93. Van der Vorst, M.M.; Kist-van Holthe, J.E.; den Hartigh, J.; van der Heijden, A.J.; Cohen, A.F.; Burggraaf, J. Absence of tolerance and toxicity to high-dose continuous intravenous furosemide in haemodynamically unstable infants after cardiac surgery. Br. J. Clin. Pharmacol. 2007, 64, 796-803.

94. Van der Vorst, M.M.; Wildschut, E.; Houmes, R.J.; Gischler, S.J.; Kist-van Holthe, J.E.; Burggraaf, J.; van der Heijden, A.J.; Tibboel, D. Evaluation of furosemide regimens in neonates treated with extracorporeal membrane oxygenation. Crit. Care 2006, 10, R168.

95. Kron, B.G.; Sjöström, P.A.; Karlberg, B.E.; Odlind, B.G. Acute tolerance to furosemide. Pretreatment with captopril or prazosin does not influence diuresis and natriuresis. Scand. J. Urol. Nephrol. 1994, 28, 337-344.

96. Hammarlund, M.M.; Odlind, B.; Paalzow, L.K. Acute tolerance to furosemide diuresis in humans. Pharmacokinetic-pharmacodynamic modeling. J. Pharmacol. Exp. Ther. 1985, 233, 447-453.

97. Bahrami, K.R.; van Meurs, K.P. ECMO for neonatal respiratory failure. Semin. Perinatol. 2005, 29, 15-23.

98. McNally, H.; Bennett, C.C.; Elbourne, D.; Field, D.J. UK Collaborative ECMO Trial Group UK collaborative randomised trial of neonates extracorporeal membrane oxygenation. Lancet 1996, $684,75-82$. 
99. Elbourne, D.; Field, D.; Mugford, M. Extracorporeal membrane oxygenation for severe respiratory failure in newborn ifants. Cochchrane Database Syst. Rev. 2002, 1, CD001340.

100. Van der Vorst, M.M.; den Hartigh, J.; Wildschut, E.; Tibboel, D.; Burggraaf, J. An exploratory study with an adaptive continuous intravenous furosemide regimen in neonates treated with extracorporeal membrane oxygenation. Crit. Care 2007, 11, R111.

101. Buck, M.L. Pharmacokinetic changes during extracorporeal membrane oxygenation: implications for drug therapy of neonates. Clin. Pharmacokinet. 2003, 42, 403-417.

102. Kugelman, A.; Durand, M.; Garg, M. Pulmonary effect of inhaled furosemide in ventilated infants with severe bronchopulmonary dysplasia. Pediatrics 1997, 99, 71-75.

103. Bar, A.; Srugo, I.; Amirav, I.; Tzverling, C.; Naftali, G.; Kugelman, A. Inhaled furosemide in hospitalized infants with viral bronchiolitis: a randomized, double-blind, placebo-controlled pilot study. Pediatr. Pulmonol. 2008, 43, 261-267.

104. Prabhu, V.G.; Keszler, M.; Dhanireddy, R. Pulmonary function changes after nebulised and intravenous frusemide in ventilated premature infants. Arch. Dis. Child. Fetal Neonatal Ed. 1997, 77, F32-F35.

105. Ohki, Y.; Nako, Y.; Koizumi, T.; Morikawa, A. The effect of aerosolized furosemide in infants with chronic lung disease. Acta Paediatr. 1997, 86, 656-660.

106. Rastogi, A.; Luayon, M.; Ajayi, O.A.; Pildes, R.S. Nebulized furosemide in infants with bronchopulmonary dysplasia. J. Pediatr. 1994, 125, 976-979.

107. Belik, J.; Spitzer, A.R.; Clark, B.J.; Gewitz, M.H.; Fox, W.W. Effect of early furosemide administration in neonates with respiratory distress syndrome. Pediatr. Pulmonol. 1987, 3, 219-225.

108. Lee, B.S.; Byun, S.Y.; Chung, M.L.; Chang, J.Y.; Kim, H.Y.; Kim, E.A.; Kim, K.S.; Pi, S.Y. Effect of furosemide on ductal closure and renal function in indomethacin-treated preterm infants during the early neonatal period. Neonatology 2010, 98, 191-199.

109. Brion, L.P.; Campbell, D.E. Furosemide for symptomatic patent ductus arteriosus in indomethacin-treated infants. Cochrane Database Syst. Rev. 2001, 3, CD001148.

110. Green, T.P.; Thompson, T.R.; Johnson, D.E.; Lock, J.E. Furosemide promotes patent ductus arteriosus in premature infants with the respiratory-distress syndrome. N. Engl. J. Med. 1983, 308, 743-748.

111. Friedman, Z.; Demers, L.M.; Marks, K.H.; Uhrmann, S.; Maisels, M.J. Urinary excretion of prostaglandin E following the administration of furosemide and indomethacin to sick low-birthweight infants. J. Pediatr. 1978, 93, 512-515.

112. Yeh, T.F.; Wilks, A.; Singh, J.; Betkerur, M.; Lilien, L.; Pildes, R.S. Furosemide prevents the renal side-effects of indomethacin therapy in premature infants with patent ductus arteriosus. J. Pediatr. 1982, 101, 433-437.

113. Schwartz, G.H.; David, D.S.; Riggio, R.R.; Stenzel, K.H.; Rubin, A.L. Ototoxicity induced by furosemide. N. Engl. J. Med. 1970, 282, 1413-1414.

114. Morelli, O.H.; Moledo, L.I.; Alanis, E.; Gaston, O.L.; Terzaghi, O. Acute effects of high doses of frusemide in patients with chronic renal failure. Postgrad. Med. J. 1971, 47, 29-35.

115. Fries, D.; Pozet, N.; Dubois, N.; Traeger, J. The use of large doses of frusemide in acute renal failure. Postgrad. Med. J. 1971, 47, 18-20. 
116. Rastogi, S.P.; Volans, G.; Elliott, R.W.; Eccleston, D.W.; Ashcroft, R.; Webster, D.; Kerr, D.N. High dose frusemide in the treatment of hypertension in chronic renal insufficiency and of terminal renal failure. Postgrad. Med. J. 1971, 47, 45-53.

117. Rifkin, S.I.; de Quesada, A.M.; Pickering, M.J.; Shires, D.L., Jr. Deafness associated with oral furosemide. South Med. J. 1978, 71, 86-88.

118. Keefe, P.E. Ototoxicity from oral furosemide. Drug Intell. Clin. Pharm. 1978, 12, 428.

119. Gallagher, K.L.; Jones, J.K. Furosemide-induced ototoxicity. Ann. Intern. Med. 1979, 91, 744-745.

120. Wigand, M.E.; Heidland, A. Ototoxic side-effects of high doses of frusemide in patients with uremia. Posgrad. Med. J. 1971, 47, 54-56.

121. Lloyd-Mostyn, R.H.; Lord, I.J. Ototoxicity of intravenous frusemide. Lancet 1971, 2, 1156.

122. Quick, C.A.; Hoppe, W. Permanent deafness associated with furosemide administration. Ann. Otol. Rhinol. Laryngol. 1975, 84, 94-101.

123. Kshirsagar, N.A.; Dahanukar, S.A.; Shah, B.P.; Vora, K.K.; Karandikar, S.M.; Acharya, V.N.; Sheth, U.K. Furosemide pharmacokinetics and its relevance to ototoxicity. J. Postgrad. Med. 1978, 24, 20-23.

124. Borradori, C.; Fawer, C.L.; Buclin, T.; Calame, A. Risk factors of sensorineural hearing loss in preterm infants. Biol. Neonate 1997, 71, 1-10.

125. Rybak, L.P. Pathophysiology of furosemide ototoxicicy. J. Otolaryngol. 1982, 11, 127-133.

126. Rybak, L.P.; Whitworth, C.; Scott, V.; Weberg, A. Ototoxicity of furosemide during development. Laryngoscope 1991, 101, 1164-1174.

127. Giapros, V.; Tsoni, C.; Challa, A.; Cholevas, V.; Argyropoulou, M.; Papadopoulou, F.; Siomou, E.; Drougia, A.; Andronikou, S. Renal function and kidney length in preterm infants with nephrocalcinosis, a longitudinal study. Pediatr. Nephrol. 2011, 26, 1873-1880.

128. Nasseri, F.; Azhir, A.; Rahmanian, S.; Iranpour, R.; Adibi, A. Nephrocalcinosis in very low birth weight infants. Saudi J. Kidney Dis. Transpl. 2010, 21, 284-289.

129. Gimpel, C.; Krause, A.; Franck, P.; Krueger, M.; von Schnakenburg, C. Exposure to furosemide as the strongest risk factor for nephrocalcinosis in preterm infants. Pediatr. Int. 2010, 52, 51-56.

130. Ketkeaw, K.; Thaithumyanon, P.; Punnahitananda, S. Nephrocalcinosis in very low birth weight infants: a single center experience. J. Med. Assoc. Thai. 2004, 87, S72-S77.

131. Pope, J.C., 4th; Trusler, L.A.; Klein, A.M.; Walsh, W.F.; Yared, A.; Brock, J.W., 3rd. The natural history of nephrocalcinosis in premature infants treated with loop diuretics. J. Urol. 1996, 156, 709-712.

132. Alon, U.S.; Scagliotti, D.; Garola, R.E. Nephrocalcinosis and nephrolithiasis in infants with congestive heart failure treated with furosemide. J. Pediatr. 1994, 125, 149-151.

133. Downing, G.J.; Egelhoff, J.C.; Daily, D.K.; Thomas, M.K.; Alon, U. Kidney function in very low birth weight infants with furosemide-related renal calcifications at ages 1 to 2 years. J. Pediatr. 1992, 120, 599-604.

134. Downing, G.J.; Egelhoff, J.C.; Daily, D.K.; Alon, U. Furosemide-related renal calcifications in the premature infant. A longitudinal ultrasonographic study. Pediatr. Radiol. 1991, 21, 563-565.

135. Jequier, S.; Kaplan, B.S. Echogenic renal pyramids in children. J. Clin. Ultrasound 1991, 19, 85-92. 
136. Kenney, I.J.; Aiken, C.G.; Lenney, W. Frusemide-induced nephrocalcinosis in very low birth weight infants. Pediatr. Radiol. 1988, 18, 323-325.

137. Hufnagle, K.G.; Khan, S.N.; Penn, D.; Cacciarelli, A.; Williams, P. Renal calcifications: A complication of long-term furosemide therapy in preterm infants. Pediatrics 1982, 70, 360-363.

138. Chang, H.Y.; Hsu, C.H.; Tsai, J.D.; Li, S.T.; Hung, H.Y.; Kao, H.A.; Chang, J.H.; Chung, H.Y.; Wang, H.K. Renal calcification in very low birth weight infants. Pediatr. Neonatol. 2011, 52, 145-149.

139. Srivastava, T.; Kats, A.; Martin, T.J.; Pompolo, S.; Alon, U.S. Parathyroid-hormone-related protein-mediated hypercalcemia in benign congenital mesoblastic nephroma. Pediatr. Nephrol. 2011, 26, 799-803.

140. Nair, S.; Nair, S.G.; Borade, A.; Ramakrishnan, K. Hypercalcemia and metastatic calcification in a neonate with subcutaneous fat necrosis. Indian J. Pediatr. 2009, 76, 1155-1157.

141. Pradhan, M.; Leonard, M.B. Calcium-free hemodialysis for hypercalcemia of malignancy in a newborn. Pediatr. Nephrol. 2003, 18, 474-476.

142. Horinek, D.; Cihar, M.; Tichy, M. Current methods in the treatment of posthemorrhagic hydrocephalus in infants. Bratisl. Lek. Listy 2003, 104, 347-351.

143. Whitelaw, A.; Kennedy, C.R.; Brion, L.P. Diuretic therapy for newborn infants with posthemorrhagic ventricular dilatation. Cochrane Database Syst. Rev. 2001, 2, CD002270.

144. Libenson, M.H.; Kaye, E.M.; Rosman, N.P.; Gilmore, H.E. Acetazolamide and furosemide for posthemorragic hydrocephalus of the newborn. Pediatr. Neurol. 1999, 20, 185-191.

145. Stafstrom, C.E.; Gilmore, H.E.; Kurtin, P.S. Nephrocalcinosis complicating medical treatment of posthemorragic hydrocephalus. Pediatr. Neurol. 1992, 8, 179-182.

146. Shinnar, S.; Gammon, K.; Bergman, E.W., Jr.; Epstein, M.; Freeman, J.M. Management of hydrocephalus in infancy: use of acetazolamide and furosemide to avoid cerebrospinal fluid shunts. J. Pediatr. 1985, 107, 31-37.

147. Eades, S.K.; Christensen, M.L. The clinical pharmacology of loop diuretics in the pediatric patient. Pediatr. Nephrol. 1998, 12, 603-616.

148. Van der Vorst, M.M.; Kist, J.E.; van der Heijden, A.J.; Burggraaf, J. Diuretics in pediatrics: current knowledge and future prospects. Paediatr. Drugs 2006, 8, 245-264.

149. Atkinson, S.A.; Shah, J.K.; McGee, C.; Steele, B.T. Mineral excretion in premature infants receiving various diuretic therapies. J. Pediatr. 1988, 113, 540-545.

150. Cappiello, M.; Giuliani, L.; Rane, A.; Pacifici, G.M. 5'-Diphosphoglucuronic acid (UDPGA) in the human fetal liver, kidney and placenta. Eur. J. Drug Metab. Pharmacokin. 2000, 25, 161-164.

151. Beermann, B.; Dalén, E.; Lindström, B.; Rosén, A. On the fate of furosemide in man. Eur. J. Clin. Pharmacol. 1975, 9, 51-61.

152. Beermann, B.; Dalén, E.; Lindström, B. Elimination of furosemide in healthy subjects and in those with renal failure. Clin. Pharmacol. Ther. 1977, 22, 70-78.

153. Calesnick, B.; Christensen, J.A.; Richter, M. Absorption and excretion of furosemide-S35 in human subjects. Proc. Soc. Exp. Biol. Med. 1966, 123, 17-22.

154. Hook, J.B.; Williamson, H.E. Influence of probenecid and alterations in acid-base balance of the saluretic activity of furosemide. J. Pharmacol. Exp. Ther. 1965, 149, 404-408. 
155. Segar, J.L.; Robillard, J.E.; Johnson, K.J.; Bell, E.F.; Chemtob, S. Addition of metolazone to overcome tolerance to furosemide in infants with bronchopulmonary dysplasia. J. Pediatr. 1992, 120, 966-973.

(C) 2013 by the authors; licensee MDPI, Basel, Switzerland. This article is an open access article distributed under the terms and conditions of the Creative Commons Attribution license (http://creativecommons.org/licenses/by/3.0/). 